\title{
Pelton Ladder Master Plan
}

\section{Technical Report}

\section{1}

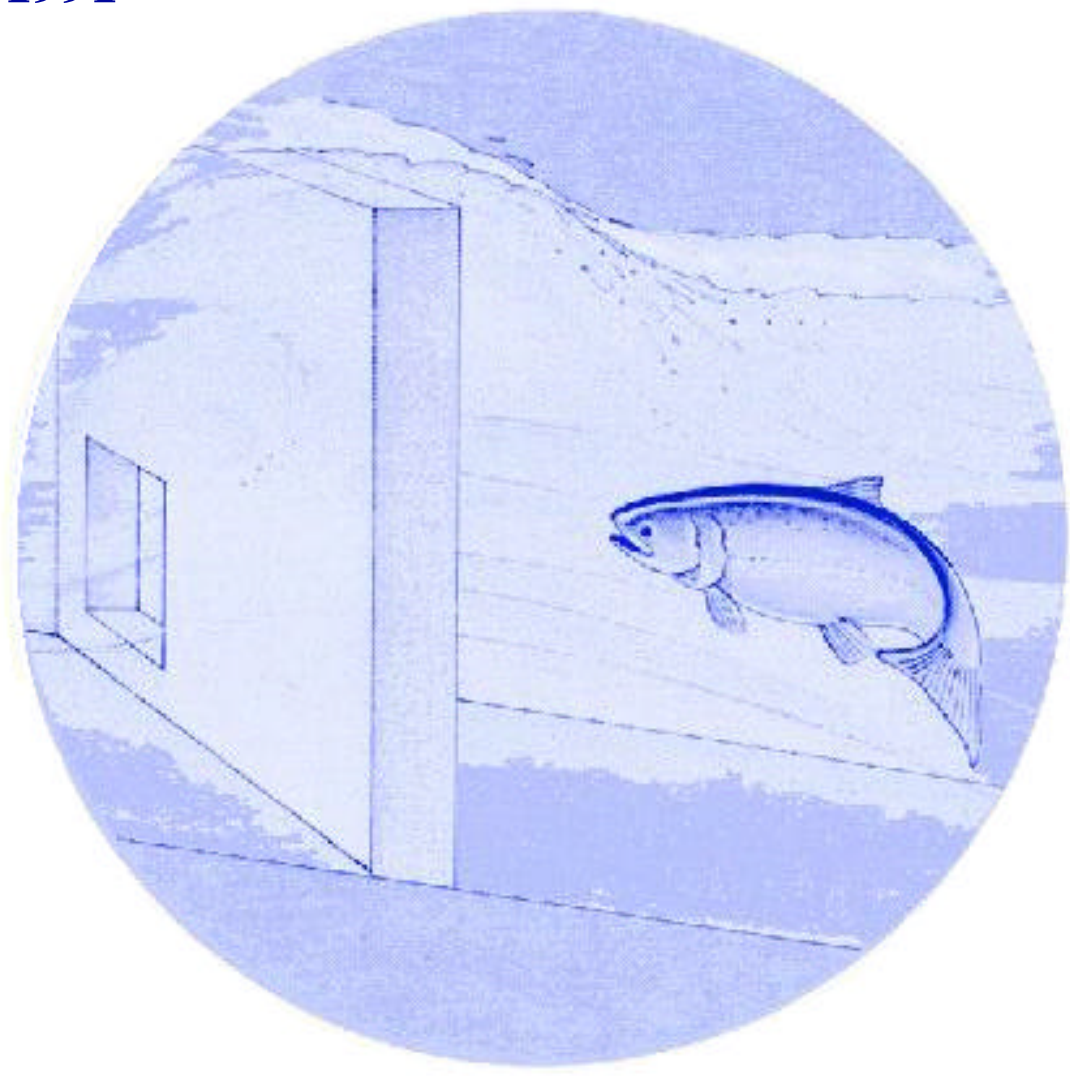

DOE/BP-01930-1

July 1991 
This Document should be cited as follows:

Smith, Max, Confederated Tribes of the Warm Springs Reservation of Oregon, "Pelton

Ladder Master Plan", Project No. 1989-02900, 72 electronic pages, (BPA Report

DOE/BP-01930-1)

\author{
Bonneville Power Administration \\ P.O. Box 3621 \\ Portland, Oregon 97208
}

This report was funded by the Bonneville Power Administration (BPA), U.S. Department of Energy, as part of BPA's program to protect, mitigate, and enhance fish and wildlife affected by the development and operation of hydroelectric facilities on the Columbia River and its tributaries. The views in this report are the author's and do not necessarily represent the views of BPA. 


\title{
PELTON LADDER MASTER PLAN
}

\author{
Prepared by \\ Max Smith \\ Oregon Department of Fish and Wildlife \\ and \\ The Confederated Tribes of the Warm Springs Reservation of Oregon \\ Prepared for \\ Jerry Bauer, Project Manager \\ U.S. Department of Energy \\ Bonneville Power Administration \\ Division of Fish and Wildlife \\ P.O. Box 3621 \\ Portland, OR 97208-3621 \\ Project No. 89-029 \\ Contract Number DE-B179-89BP01930 \\ July, 1991
}




\section{TABLE OF CONTENTS}

EXECUTIVE SUMMARY.

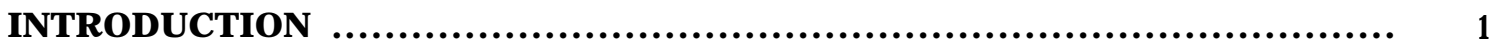

Background ........................................................... 1

Project Goals.......................................................... 2

Production Policies and Procedures ......................................... 4

Production Management Structure and Processes .................................. 6

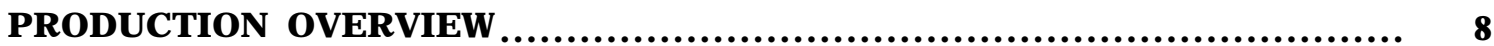

Production Objectives ................................................. 8

Production Methods and Strategies .......................................... 9

Broodstock Management and Acquisition ................................... 12

Production Profiles......................................................... 13

Management and Production History of Deschutes Spring Chinook ............. 18

Concerns, Uncertainties, and Solutions to Problems ........................ 21

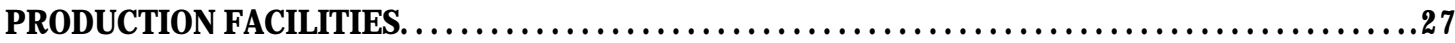

SUPPLE ME NTATION PLANS

Release Sites ....................................................... 29

Supplementation Opportunities and Constraints.. .............................29

Genetic Risk Analysis ................................................ 31

HARVEST GUIDELINES AND FISHERY BENEFITS............................ 36

MONITORING AND EVALUATION PLAN $\ldots \ldots \ldots \ldots \ldots \ldots \ldots \ldots \ldots \ldots \ldots \ldots \ldots \ldots \ldots, \quad 38$

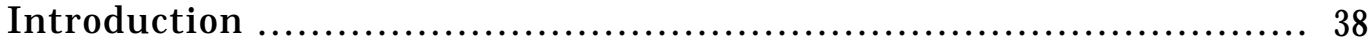

Uncertainties and Potential Impacts ..................................... 38

Experimental Approach ................................................ 44

Hatchery Effectiveness Experiments................................... 50

Recommendations for Fish Releases and Release Sites ..................... .52

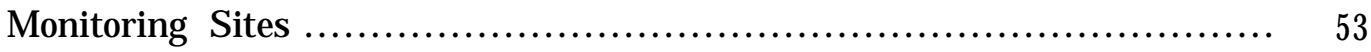

MANAGEMENT POLICIES AND GUIDELINES ..............................54

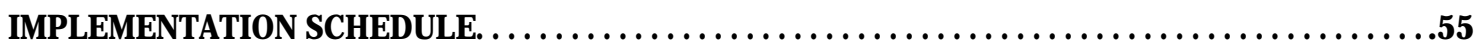

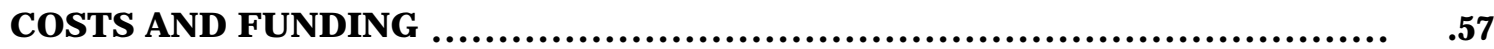

Services and Supplies, Operations and Maintenance ...................... .57

Capital Costs .......................................................................... 57

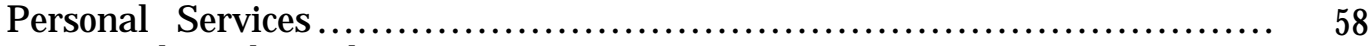

Estimated Study Budget ............................................ 59

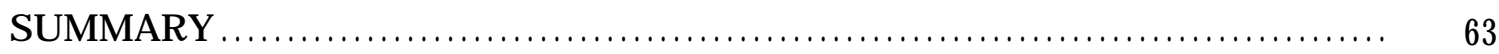

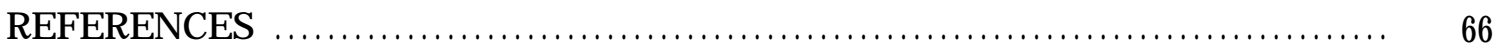




\section{EXECUTIVE SUMMARY}

\section{Introduction}

The Northwest Power Planning Council's (Council) Columbia River Basin Fish and Wildlife Program (Program) set a goal to substantially increasing the current runs of Columbia River salmon and steelhead. This increase in fish runs is designed to offset losses of salmon and steelhead resulting from the development and operation of the Columbia River hydropower system.

In its amended (1987) Fish and Wildlife Program, the Council included a goal to increase fish production at Pelton Ladder as a low-capital means of contributing to additional adult returns in the Columbia Basin and Deschutes River Subbasin. The Council's Program further specified that the Oregon Department of Fish and Wildlife (ODFW) and Confederated Tribes of the Warm Springs Reservation of Oregon (CTWS) prepare a master plan prior to any design and construction.

\section{Project Background}

Pelton Ladder is an adult fishway extending from below Pelton Regulating Dam to the Pelton Dam, which impounds Lake Simtustus. The ladder is 10 feet wide, 6 feet deep, and 2.8 miles long. It was originally designed and constructed to allow passage of adult chinook salmon and summer steelhead around the reregulating dam to Lake Simtustus. However, the ladder was abandoned for adult passage after the facilities at Round Butte Dam (located above Pelton Dam) failed to effectively pass juvenile salmonids downstream.

In recent years, Pelton Ladder has been modified and put to new use as a rearing site for some of juvenile spring chinook produced at the Round Butte Hatchery (RBH). This hatchery, funded by Portland General Electric (PGE), was developed to mitigate for losses of spring chinook and summer steelhead caused by the Pelton-Round Butte hydroelectric projects. RBH currently produces 270,000 spring chinook smolts as part of this mitigation effort.

As part of the RBH production program, 80 percent of the spring chinook (210,000 juveniles) reared at the hatchery are transferred to Pelton Ladder in November. These fish over-winter and are allowed to volitionally migrate out of the ladder in April. The remaining 20 percent of the spring chinook production (60,000 juveniles) are reared at the hatchery and released in the spring.

The use of Pelton Ladder for rearing juvenile spring chinook has proven to be a feasible and successful means for increasing adult returns. Spring chinook smolts rear well in the ladder, apparently benefiting from the semi-natural rearing conditions. Smolts reared in the ladder have helped achieve increased adult returns to the Deschutes River Subbasin. Survival from smolt to adult return to the Deschutes River has averaged 1.6 percent.

Currently, rearing in the ladder takes place in the modified lower portion of the ladder. This existing rearing space represents only 20 percent of the available ladder capacity suitable for rearing fish. Therefore, it is estimated that the ladder could potentially accommodate almost five times the existing production level. 


\section{Project Goals}

The overall goal of this project, as stated in 703 (g) (3) of the Council's Fish and Wildlife Program, is to expand the spring chinook production capability of Pelton Ladder. Specifically, this project proposes to create three additional rearing cells in Pelton Ladder. These modifications will allow the capability to rear 187,000 spring chinook smolts (23,331 pounds). This would approximately double the existing rearing capacity of the ladder.

The goal for this project implies that there is also a need to conduct corollary studies to assure (1) the project is completed efficiently, (2) smolts are of good quality and provide the desired levels of adult return, and (3) the project adequately addresses the ecological and genetic elements of the river and hatchery environments. A monitoring and evaluation plan is presented to determine if the project is meeting the stated goals.

\section{Production Strategies}

Additional spring chinook juveniles to be raised will be derived from broodstock collected at Pelton Ladder. An additional 210 adults and 21 jacks would need to be collected to meet the project's broodstock requirements.

Because RBH is operating at full capacity, some modifications are needed to accommodate the expanded production. This plan proposes that this be accomplished by modifying the RBH ponding strategy--moving some of the fingerlings from RBH to Pelton Ladder in September, two months earlier than current program. This would reduce loading density in the $\mathrm{RBH}$ rearing ponds to acceptable levels.

Initial production methods and strategies for the new ladder production will be similar to the current hatchery and ladder production methods used at $\mathrm{RBH}$, with some modifications.

\section{Release Strategies}

In order to maintain a balanced coexistence of hatchery and natural stocks in the Deschutes River Subbasin, this plan proposes that only a moderate number (e.g., approximately one-third) of the new production smolts be released into the Deschutes River. The remaining smolts would be transported to the Hood River Subbasin to be used in re-establishing runs of spring chinook using a more locally adapted stock.

Release of the new ladder-reared smolts will follow the current strategy--liberation as yearlings in the second spring following egg-take (18 months). The target release size for the ladder-reared smolts is currently 9 fish/lb. Different target sizes at release will be evaluated as part of the monitoring and evaluation plan.

\section{Production Facilities}

Expanded production in the ladder will require only minor physical modifications to the hatchery and the fish ladder. Since the intent of the proposed project is to retain the small-scale, low-capital nature of the existing program, no new major facilities are envisioned to meet new production goals. 


\section{Monitoring and Evaluation}

A monitoring and evaluation plan has been developed to assess whether program goals are being met. One of the implied program goals is to evaluate the ladder's ability to effectively produce spring chinook smolts. This infers that if the proposed expansion is successful, it may be possible to further increase the ladder's fish rearing capability. The program goals also include the need to identify hatchery practices at the RBH/Pelton Ladder complex that not only promote improved smolt-to-adult survival rates, but also protect naturally rearing fish in the Deschutes River Subbasin.

Specific hatchery-effectiveness experiments within the monitoring and evaluation plan include controlled tests with tagged smolts to assess effects of smolt size on survival rate; survival effects associated with the timing of juvenile transfer (i.e., when juveniles are moved from $\mathrm{RBH}$ to Pelton Ladder), and continued comparison of the relative survival rates observed between RBHproduced and Pelton Ladder-produced smolts. Field studies are designed to document possible genetic impacts: harvest of adults produced, potential changes in hatchery/natural composition of the catch, and potential changes in rate of straying of hatchery-generated adults into natural production areas.

\section{Project Costs}

Based on preliminary estimates, it is felt that the necessary capital improvements can be accomplished for less than $\$ 100,000$. The estimated total cost for the project-related fish production and studies (FY 1992 - 99) is approximately $\$ 200,000$ - $\$ 250,000$ per year.

\section{Project Benefits}

The proposed Pelton Ladder project offers a number of important benefits:

- Rearing additional fish in Pelton Ladder provides a means of increasing artificial production without major capital construction costs associated with building a new hatchery.

- Adult chinook returning from this rearing program will help bolster the dwindling runs of "upriver" spring chinook, thus assisting the Council's goal for increased production of this species.

- Because of their unique survival and adult-production attributes, low cost and excellent quality, the spring chinook smolts produced in Pelton Ladder represent an unparalleled opportunity to restore or improve runs in other Columbia River tributaries that may be designated as appropriate donor streams.

- Spring chinook released from Pelton Ladder will provide a number of harvest benefits. Based on past performance, approximately 6 percent of the adults produced will be caught in sport, commercial, and tribal subsistence fisheries in the Columbia River. Most benefits of the extra adults produced, however, will be realized in the Deschutes River in the form of increased sport and tribal harvests and increased returns to RBH. Adults collected at Pelton Ladder above production needs will be provided to the CTWS.

- The associated monitoring and evaluation studies will refine ODFW's ability to effectively mange the RBH/Pelton Ladder rearing program. These studies will also provide information needed to evaluate the feasibility of further expanding the fish-rearing potential of the ladder. 


\section{INTRODUCTION}

\section{Background}

The Northwest Power Planning Council's (Council) Columbia River Basin Fish and Wildlife Program stipulated a goal of substantially increasing the current runs of Columbia River salmon and steelhead. This increase in fish return is designed to offset losses of salmon and steelhead that have occurred with the development of the Columbia River hydropower system (NPPC 1987). Deschutes River spring and fall chinook salmon (Oncorhynchus tshaurytscha) and summer steelhead (Oncorhynchus mykiss) populations have been adversely affected by the construction of Bonneville and The Dalles dams, the two lowermost mainstem dams on the Columbia River, as well as the Pelton-Round Butte hydroelectric complex on the Deschutes River. Portland General Electric Company (PGE) is obligated to mitigate for losses of spring chinook salmon and summer steelhead caused by the Pelton-Round Butte hydroelectric projects. This mitigation is provided by PGE-funded hatchery production at Round Butte Hatchery (RBH). However, no off-site mitigation for losses of Deschutes River anadromous fish at Bonneville and The Dalles dams on the Columbia River has been provided.

Mitigating the effects of the federal hydroelectric system on Deschutes River salmon and attaining the Columbia River Basin goal for returns of adults will depend, in part, on increased production of salmonids in the Deschutes River Subbasin. However, it is not possible to mitigate effects of the federal dams on Deschutes River salmon through natural production alone because major production areas in the Deschutes were blocked by construction of Pelton and Round Butte dams. Increased hatchery production must also be used to fully reach run-size goals and mitigate losses.

Measure $703(\mathrm{~g})(3)$ of the Council's amended (1987) Fish \& Wildlife Program identified a goal for expanding production of salmon or steelhead in the fish ladder at Pelton Dam on the Deschutes River as a low-capital means of contributing to additional adult returns. This increased production would be in addition to the spring chinook salmon rearing currently being funded in Pelton Ladder by PGE. Based on experiences with rearing salmon in Pelton Ladder, it is believed that the ladder has potential for effectively producing many more anadromous salmonids. RBH's production program currently consists of annually rearing and releasing 60,000 spring chinook salmon smolts from the hatchery and 210,000 smolts from Pelton Ladder. The aim of this chinook production is to achieve the mitigation level of 1,200 adults returning to Pelton trap each year. Increasing artificial production in the fish ladder at Pelton Dam provides a potential for inexpensively rearing smolts as off-site mitigation, contributing to goals for adult return, and providing increased harvest opportunities in the Columbia River, Deschutes River Subbasin, and other subbasins with outplanting potential.

The Deschutes River Subbasin Plan, currently being reviewed for adoption, identified a priority need for increased natural and artificial production of spring chinook salmon. Although increases in run size for summer steelhead and fall chinook and development of a selfsustaining sockeye salmon (Oncorhynchus nerka) run were recommended in the subbasin plan, additional artificial production of these species was assigned lower priority. Based on existing hatchery and natural production levels and estimated production potential, the goal for spring chinook salmon outlined in the subbasin plan is for an annual return of 8,500 to 12,000 adults to the lower Deschutes River Subbasin. This would be an increase of 2,000 to 5,500 more adult spring chinook salmon returning to the river each year. An integral component of the subbasin plan's preferred strategy for increasing spring chinook salmon returns is an increase in production at $\mathrm{RBH}$ through additional smolt rearing in Pelton Ladder. 


\section{Project Goals}

The goal of this project, as stated in $703(\mathrm{~g})$ (3) of the Council's Fish and Wildlife Program, is to expand the spring chinook production capability of Pelton Ladder. There is also a critical need to conduct supporting studies to assure (1) that the project is conducted efficiently, and (2) that the project will addresses ecological and genetic elements of the river and hatchery program.

This projected expansion of rearing in Pelton Ladder will be distinct from the rearing program currently funded by PGE. Based on an observed smolt-to-adult survival rate of 1.6 percent (Lindsay et al. 1989), each additional increase of 10,000 smolts released from Pelton Ladder will contribute an additional 160 adult return to the Deschutes River or other acceptable Columbia River subbasin. Although the actual rearing potential of the ladder is unknown, it is likely substantially more than what is currently used--only 6 percent of the available ladder space and 20 percent of the available ladder flow capacity is currently used to produce about 23,000 pounds of smolts.

Implementation of the Pelton Ladder project would require only minor facility modifications. Therefore, the project offers an excellent opportunity for increasing artificial production without major capital construction costs associated with building a new hatchery. Other rearing advantages offered by the ladder include the following:

- A semi-natural rearing environment that includes natural aquatic organisms to supplement artificial feeding

- Relatively low rearing densities

- The opportunity for smolts to volitionally migrate directly into the Deschutes River

An increase in run size could be a positive economic benefit to the area by enhancing a managed recreational fishery and traditional tribal harvest. Smolts produced in excess of the number desired to release in the Deschutes River Subbasin will be made available for outplanting to other acceptable Columbia River tributaries. An increase in the number of adults provided to the Confederated Tribes of the Warm Springs Reservation (CWTS) is also expected, since there will be more adult returns to the Pelton Ladder than will be needed for broodstock purposes.

Learning benefits and opportunities for adaptive management will be derived from the monitoring and evaluation program. This program will use adaptive management techniques in designing, implementing and improving effectiveness of the existing and proposed propagation programs at RBH/Pelton Ladder. The existing management processes can be quickly accessed to modify fish cultural, harvest management, or other fish management activities as project results justify.

The ladder-rearing production program. is a unique approach to artificial propagation. The project offers an excellent opportunity for testing and refining existing production strategies and techniques at RBH. The monitoring and evaluation plan includes assessments of the potential to rear more fish in Pelton Ladder, refinement of production techniques, survival effects of smolt size, optimal rearing and production strategies and methods, assessment of control strategies for diseases and parasites, and practical experience with operations designed to maintain genetic resources.

The Deschutes River Subbasin Plan (ODFW 1989) identified local subbasin opportunities and constraints with regard to production plans for salmon and steelhead stocks. The objectives outlined for spring chinook salmon production reflect the overall system planning goal and 
policies of the Council and the state and tribal management guidelines for natural and hatchery fish. Spring chinook salmon in the mainstem Deschutes River are to be managed for a combined population of natural and hatchery fish (Oregon Administrative Rules 635-07-510 (2) (b)). Subbasin objectives for spring chinook salmon production and harvest, which follow this management guideline and conform to the system policies for increased production and harvest, are to:

- Enhance natural production through optimum utilization of existing and potential habitat.

- Provide 5,500 to 8,000 spring chinook available for harvest in tribal and non-tribal fisheries through an annual return of 8,500 to 12,000 fish.

- Increase overall harvest opportunities for both natural and hatchery stock.

- Provide an opportunity for equitable harvest sharing of spring chinook salmon in tribal and non-tribal fisheries.

The subbasin plan recommended several strategies to meet these objectives including (1) increased natural production through habitat and passage enhancement and passage barrier removal, and (2) increased hatchery production. Enhancement and expansion of natural production would be achieved through improvement of riparian habitat in Shitike Creek and Warm Springs River. These are the major areas in the Deschutes River Subbasin where natural production of spring chinook has been identified.

Since Deschutes River spring chinook are not under-escaped, habitat expansion and enhancement should result in immediate production increases. In addition, a project has been proposed (and a feasibility study completed) to provide anadromous fish passage over White River Falls. If implemented, this project would open substantial spawning and rearing habitat now inaccessible to salmon. Subsequent introductions of spring chinook could potentially establish natural production of 1,200 to 3,000 adults in the White River. Proposed increases in hatchery production would occur at RBH through the expanded Pelton Ladder project and by bringing the Warm Springs National Fish Hatchery (WSNFH) to its full production capacity of 1.2 million smolts through an evaluation of rearing and release practices.

The Deschutes River Subbasin Plan also considers providing fish passage past the Pelton-Round Butte hydroelectric project. However, implementation of this program would rely on future development of effective technology to efficiently collect and safely pass juvenile fish from above Round Butte and Pelton dams. This passage project would provide access to historic spawning and rearing habitat currently blocked by the Pelton/Round Butte hydroelectric project. This action is the recommended strategy in the Deschutes Subbasin Plan for developing and maintaining selfsustaining runs of sockeye salmon in the Deschutes River.

Expanding production at existing hatchery facilities follows system policies and goals envisioned in the Council's Fish and Wildlife Program for increasing salmon runs. As stated in the Deschutes Subbasin Plan, the goal for increased spring chinook production cannot, and should not, be met through natural production alone. The existing level of artificial production in the Deschutes River has had unmeasurable impact on the genetic character of the subbasin population of spring chinook. This judgement is based on the extreme care given by managers to maintain spatial segregation of the hatchery and natural populations; the continuing process of selectively removing hatchery fish from adult returns to the upper Warm Springs River through adulttrapping operations at WSNFH; and, the observed minimal straying of hatchery adults into Shitike Creek. 
Moderate increases in smolt production in Pelton Ladder will likely continue to show unmeasurable low effects on genetic character of Deschutes spring chinook. Monitoring indications of interactions between hatchery and wild chinook will continue over time. The ability of the natural stock to maintain itself in the face of increased hatchery production and potential harvest increases remains an uncertainty; however, the existing management and structure program takes extreme care to isolate and protect the natural production potential of the lower Deschutes River Subbasin.

Concurrent implementation of efforts to increase both the hatchery and natural components of the run is advocated. Enhancement of natural production through habitat improvements in the Warm Springs River and Shitike Creek are unlikely to provide sufficient natural production to offset the effects of greatly increased hatchery production within the Deschutes River Subbasin. Only implementation of the proposed White River project appears to have that potential. However, several problems need to be overcome before passage at White River Falls can be considered (ODFW et al. 1985).

Management of spring chinook in the Deschutes River system is benefitted by the capability to integrate management of hatchery and natural spring chinook populations. All hatcheryproduced smolts are given fin marks. When these fish return as adults, fin-marked hatchery fish can be separated from natural stocks. This allows managers to observe relative abundance and location of return of hatchery and natural fish. For example, marked hatchery adults are currently prevented from entering the Warm Springs River above WSNFH. The ability to visually distinguish hatchery from natural stocks provides fishery managers a variety of tools to specify harvest and production interventions based on stock of origin.

Currently available broodstock and water supplies at RBWPelton Ladder are sufficient to permit expansion of artificial production programs. Use of existing adult returns as broodstock would avoid potential problems associated with transfers of spring chinook salmon into the subbasin from outside sources. Because the Deschutes River lies above only two mainstem Columbia River dams, increasing production here benefits from a locational advantage over similar efforts that may be applied in upper Columbia River areas.

\section{Production Policies and Procedures}

Increased production of spring chinook salmon in Pelton Ladder will adhere to current policies and procedures for salmon production at $\mathrm{RBH}$, as dictated by the Oregon Administrative Rules, Chapter 635, Division 7. Tribal and federal policies regarding hatchery production are generally consistent with those of the State of Oregon. The proposed project will meet all provisions of Measure 703 (g) (3) of the Council's Fish and Wildlife Program.

A goal of fish production and management in the mainstem Deschutes River is to manage for a combination of natural and hatchery fish (OAR 635-07-510 (2b)) under the policy that hatchery and natural anadromous fish will be managed separately. Under guidelines established by ODFW, USFWS and CTWS, only minimal interbreeding in natural spawning areas will be allowed between hatchery and natural spring chinook as a means of maintaining genetic integrity of natural stocks (ODFW 1987). Implementation of this policy is facilitated through the management practice of externally marking all hatchery fish released into the subbasin. Based on provisions of the fish management policy, hatchery production must contribute to adult abundance as spawning stock or harvestable surplus (OAR 635-07-515 (7)). Artificial production at RBH currently meets these production and management goals and policies, as will the proposed expanded production in Pelton Ladder. The WSNFH program additionally emphasizes the 
preservation of natural production in the Warm Springs River/Shitike Creek systems and the retention of natural genetic traits in hatchery broodstock.

The current policy for RBH broodstock dictates that only indigenous Deschutes River stock are acceptable for release into the Deschutes River Subbasin. Broodstock management for spring chinook salmon incorporates a selection process designed to maintain genetic diversity in life history characteristics as expressed in OAR 635-07-800 ( $1 \& 2$ 2). Broodstock are collected proportionate to their abundance throughout the run. Unmarked spring chinook salmon (presumably naturally-produced) returning to Pelton trap before July 1 are also incorporated into the spawning population at a rate of $<5.0$ percent ( Bill Nyara, ODFW, personal communication). The infusion of genes from naturally-produced broodstock is theorized to aid in maintenance of genetic diversity and improvement in the ability of hatchery stock to survive in natural habitats. Although of greater practicability at WSNFH, the use of some naturally-produced adults as a component of hatchery broodstock helps to maintain similarities between hatchery and natural stocks and provides future options for supplementation should natural stocks decline. Because natural spawning has never been observed in the mainstem Deschutes River, and because RBH hatchery stock return specifically to Pelton trap with minimal straying, mixing of hatchery with natural stocks in the mainstem river is not believed to be a genetic concern in the hatchery production policy at this station.

A spawning ratio of one male to three females has been employed in the past spawning program at RBH. Females typically comprise 70 percent of the adult return. A 1:1 male to female spawning ratio was implemented in 1990 as a hatchery genetics measure. This spawning ratio adjustment was achieved by changing the broodstock collection procedure. Jacks will continue to be a spawning component in a ratio of 1 jack per 8 adults collected. Additional improvements to the broodstock collection, spawning, egg incubation, juvenile rearing, and smolt release program at $\mathrm{RBH}$ will be considered in light of concerns for ensuring the genetic diversity of the hatchery broodstock.

Release strategies for spring chinook salmon at RBH/Pelton Ladder follow ODFW policies for salmon release (OAR 635-07-810 and 815). Spring chinook salmon smolts are of a size (yearling smolt) and released at a time (spring) designed to facilitate quick emigration to the ocean. Smolts are released in a manner designed to achieve optimum survival of adults while limiting species interactions and genetic conflicts with natural fish. Hatchery fish, including ladder-reared fish, have all been released in the vicinity of Pelton Ladder, which appears to minimize straying of returning adults. In addition, the release site is spatially separated from spawning areas of natural populations. Hatchery personnel attempt to release smolts with a minimum of stress and injury to increase survival potential.

State policy for release or transfer of fish from public hatcheries requires that prior staff authorization must be obtained and disease control regulations met (OAR 635-07-820 (3)). Chinook smolts from $\mathrm{RBH}$ are examined by a fish pathologist at 30-day intervals during the rearing phase, and a pre-release health examination occurs approximately 30 days before liberation to ascertain health and disease status of the fish, as required in OAR 635-07-580. Because of the difficulty of sampling fish in the ladder cells, smolts reared in Pelton Ladder have only recently been sampled and subjected to pre-release pathology examinations. The pathology examinations conducted at $\mathrm{RBH}$ during rearing focus primarily on detection and treatment of bacterial and parasitic infection; the pre-release examinations include a virus culture. Fish infected with viruses require special treatment and clearance before they can be released. State management policies prohibit the transfer of stocks (juvenile or adult) infected with certain diseases to other non-infected areas to prevent the spread of fish diseases (OAR 635-07-565).

Fish diseases are classified by category of concern (OAR 635-07-570 and 575) and transfer restrictions based on disease categories are outlined in OAR 635-07-585. Diseases of concern at 
$\mathrm{RBH}$ include BKD, IHN, EIBS and Ceratomyxa shasta. Transfer of fish with these diseases, particularly viruses, from RBH is restricted under OAR 635-07-585. The WSNFH adheres to the same disease transfer restrictions. If transfer of fish is proposed, the policy on disease transfer restrictions must be followed, after an internal ODFW staff review. Advice or recommendations from other concerned agencies or appropriate technical work groups may be solicited to reach a final decision on transfers or releases of pathology or genetic concern.

Fish health management and procedures at $\mathrm{RBH}$ are followed in accordance with ODFW policies. $\mathrm{BKD}$ was a major health concern for spring chinook reared at RBH in the past, accounting for 0.7 to 2.2 percent mortality of the smolts reared in the ponds during October and November.

Beginning with the 1984 brood, ODFW pathologists instituted a BKD-control program consisting of two separate injections of erythromycin administered to broodstock during the collection and holding period, followed by prophylactic antibiotic feedings of subsequent progeny. After this program was initiated October/November, fingerling losses dropped to 0.1 percent and have remained stable at this greatly reduced level even after the prophylactic feedings to juveniles was discontinued (Craig Banner, ODFW Pathologist, personal communication, 1991). If necessary, the option exists to reinstate this prophylaxis of juveniles for $\mathrm{BKD}$, although the current program of injecting adults appears to be producing the desired BKD control effect.

Although infectious hemopoetic necrosis (IHN) and Erythrocytic Inclusion Body Syndrome (EIBS) exist only in a carrier state in spring chinook salmon at $\mathrm{RBH}$ (because of the particular viral strain and the natural resistance of Deschutes spring chinook to these pathogens), presence of these viruses has, in the past, restricted the ability to transfer these fish to outside unaffected areas. However, if pre-liberation examinations detect no IHN virus in smolts, transfers and outside subbasin releases are possible (Rich Holt, ODFW, personal communication). This decision has critical implications for the potential of outplanting Pelton Ladder smolts in future supplementation programs.

Cerutomyxa Shasta infections can occur in juveniles reared in the ladder as the sporozoan is present in Lake Simtustus and the Deschutes River. Infectivity of this disease appears time- or temperature-related. An initial infective period occurs from late March to mid-April, at water temperatures ranging from 6.9 to $8.6^{\circ} \mathrm{C}$, and continues to late July (Ratliff 1983). This limits ladder production to months when Cerutomyxa populations are low (see Production Profiles) and dictates releases of yearling smolts early enough in the spring to avoid time periods of high infectivity.

\section{Production Management Structure and Processes}

Expansion of smolt production in Pelton Ladder will be governed by the existing management structure and processes in place for $\mathrm{RBH}$. Key agencies currently involved in the operation and management of the facility are PGE, ODFW, and CTWS.

PGE maintains ownership of the hatchery and funds all operations as part of its mitigation responsibilities for the construction of Round Butte Dam. ODFW has operating control of the hatchery facilities and equipment, including rearing of fish in Pelton Ladder. ODFW and CTWS co-manage the fishery resources.

The proposed production in Pelton Ladder will necessarily involve the Bonneville Power Administration (BPA) as a key agency in the management structure as the project will be funded by BPA. The Council is involved as a coordination agency, and the U.S. Fish and Wildlife Service, through its operation of the only other major spring chinook production facility on the Deschutes River, has both a cooperative and supportive role. 
An annual coordination meeting of the agencies involved with production at RBH (PGE, ODFW, CTWS and USFWS) is held to provide an overview of the facility operation. This meeting includes a review of pre- and post-production programs, mitigation goals, capital improvements, budget requests, staff needs, work load, current research programs, and program modifications.

The production program at $\mathrm{RBH}$ also undergoes an annual ODFW staff review as required in OAR 635-07-820. Annual production levels are established for the hatchery and decisions on number and size of fish to be released, release dates, eggs needed for various allocations, and strategies for solving production problems are made at this time. General management guidelines and policies for hatchery operation are included in Oregon Administrative Rules 63507-810 to $635-07-830$.

Effective implementation of research results through the process of adaptive management requires a formal process of technology transfer. Changes to the production plan at $\mathrm{RBH} / \mathrm{Pelton}$ Ladder can be quickly implemented after appropriate staff consideration and with the concurrence of PGE representatives. Decisions related to production changes can be put into practice after discussions at the annual production review (usually held in early June), at semiannual Fish Management/Fish Propagation Meetings of ODFW fishery staff (usually held in April and October, although these dates are subject to vary). Urgent contingencies requiring immediate decisions may be acted upon on an as-required basis via discussion and coordination through ODFW's Fish Division, RBH management, and ODFWs Central Region supervisor; all acting in concurrence with PGE (the funding agency) and after consulting with CTWS.

There will likely be little public opposition to the concept of expanding spring chinook rearing in Pelton Ladder. This concept is an integral component of the preferred alternative for increasing production of spring chinook in the Deschutes Subbasin Plan. Development of the subbasin plan included extensive coordination and comment from not only fishery management agencies and tribal interests, but a Public Advisory Committee comprised of representatives of non-treaty user groups and interested members of the general public, as well as a Technical Advisory Committee (TAC) composed of representatives of state and federal resource management agencies, tribes, and utilities. 


\section{PRODUCTION OVERVIEW}

\section{Production Objectives}

The purpose of the proposed expansion of propagation in Pelton Ladder is to contribute, in a low-cost manner, to the spring chinook salmon production goal outlined in the Deschutes River Subbasin Plan and to the Council's system-wide goal of substantially increasing salmon runs to the Columbia River Basin. Rearing juvenile spring chinook in Pelton Ladder has proven to be a feasible and successful means for increasing adult returns. Spring chinook smolts rear well in the ladder, apparently benefitted by the semi-natural rearing conditions. The smolts are currently allowed to migrate from the ladder unhandled in early April. Survival from smolt to adult return to the Deschutes River of slow-incubated, ladder-reared spring chinook has averaged 1.6 percent. This survival rate compares favorably to total survival rates reported for spring chinook reared in many other artificial production facilities in the Pacific Northwest. The low-cost nature of the rearing phase of the project and its potential for substantially increasing smolt production at $\mathrm{RBH}$ and increasing adult returns subbasin- and basin-wide has been recognized in the Council's amended 1987 Fish and Wildlife Program (Measure 703(g)(3)) (NPPC 1987).

Augmentation of spring chinook salmon returns to the Deschutes River Subbasin would provide more fish available for harvest, more potential harvest opportunities, and the opportunity for equitable harvest sharing of spring chinook in recreational and Warm Springs tribal fisheries. The Deschutes River Subbasin Plan identified a need to increase spring chinook salmon production in the subbasin to achieve a run size goal of 8,500 to 12,000 adults. Given an achievable 1.6 percent survival rate, each 10,000 smolts reared and released from Pelton Ladder represents an additional potential return of 160 adults to the Deschutes River.

These fish will also contribute to ocean and Columbia River fisheries. Based on tag recovery information for the 1980-1984 broods, about 1 percent of the RBH adults are caught in ocean fisheries, 6 percent in mainstem Columbia River fisheries (predominantly in subsistence and ceremonial gillnet harvests), and 93 percent are accounted for within the Deschutes River Subbasin either in sport or dipnet fisheries or as returns to RBH (Mark Lewis, ODFW Technical Services, personal communication).

The Deschutes River Subbasin Plan delineated specific enhancement actions, including increased production at $\mathrm{RBH}$ through additional rearing of spring chinook in Pelton Ladder. Attainment of full production capacity at WSNFH was also recommended. However, run size and harvest objectives cannot and should not be met through increased hatchery production alone. Increased artificial production must be closely tied to corresponding enhancement of natural production, specifically developed through habitat enhancement projects. Improved spawning escapement in Warm Springs River and Shitike Creek, and provision of passage at White River Falls are mentioned. This plan recommends that increases in hatchery production be conducted coincidentally with simultaneous increases in natural production, thus helping to maintain a balanced coexistence of hatchery and natural stocks in the Deschutes River Subbasin.

Additional propagation in Pelton Ladder provides a dynamic learning opportunity through investigation of critical uncertainties as described in the Monitoring and Evaluation section. Answers to these critical uncertainties inherent in this particular unique method of artificial rearing will provide better insight into both the production potential of Pelton Ladder, and definition of effective production criteria for both the hatchery and the ladder, which may have implications for hatchery practices at other locations in the Columbia basin. 


\section{Production Methods and Strategies}

Currently, RBH is operating at full capacity. Maximum spring chinook production is 270,000 smolts (under existing facilities, current species allocation mix, and goals for smolt release size). Approximately 60,000 fish remain at the hatchery for finish-rearing while 210,000 fingerlings are transferred to Pelton Ladder in November to complete final rearing. Without ladder rearing, total smolt production from the hatchery/ladder complex would be reduced by about 23,000 pounds. Because smolts produced in the ladder have survived well, the ladder-rearing program has become a standard production strategy for spring chinook at $\mathrm{RBH}$ since 1983. It has also allowed PGE to meet, and in recent years exceed, its mitigation obligation of 1,200 spring chinook returning annually to Pelton trap (Figure 1).

To produce additional spring chinook salmon at $\mathrm{RBH}$, several options were considered including (1) building more rearing ponds to start more spring chinook, (2) decreasing the summer steelhead production, and/or (3) eliminating the brown trout production program. However, subbasin planners recommended the summer steelhead and brown trout production programs be maintained. Furthermore, building more rearing ponds at RBH would be very expensive, thus negating some of the low-cost benefits envisioned in this project. Therefore, it was determined that the most cost-effective manner to accommodate the expanded production is to modify the $\mathrm{RBH}$ ponding strategy. The proposed method would be to move some of the fingerlings started at RBH to Pelton Ladder in September, two months earlier than the existing program of November transfer. September transfer of some of the fish will reduce loading density in the RBH rearing ponds to acceptable levels. Since September transfer is not an existing program, the effects of this modification would be evaluated as part of the proposed monitoring and evaluation studies.

Pond limitations at $\mathrm{RBH}$ also complicate supplementation strategies that may eventually require isolation of stocks to rear. For example, keeping Hood River stocks separate from the Deschutes stocks while in the RBH ponds could be accomplished by modifying ponding and early-rearing strategies. However, maintaining two separate stocks is about the limit of flexibility of the existing pond structure at this facility. If isolation of additional genetic strains becomes necessary, additional pond space will have to be provided.

Initial production methods and strategies for additional ladder reared juveniles will be similar to the current hatchery- and ladder-production methods used at $\mathrm{RBH}$, as modified by TWG suggestions to improve the potential to maintain genetic integrity of the existing $\mathrm{RBH}$ broodstock. Final smolt production methods and strategies (changes in time of transfer to Pelton Ladder, changes in target size for smolt release, etc.) will evolve through an evaluation program accomplished by a process of monitoring and evaluation.

The current spring chinook salmon production program at $\mathrm{RBH}$ begins with the collection of broodstock selected from adults returning to Pelton trap--the adult collection facility below Pelton Regulating Dam. A temporally stratified, random collection of broodstock is made from May into July to ensure all run segments are represented in the population spawned. Adults are held in ponds at the hatchery until spawning in late August or early September. The spawn timing is relatively compressed; all eggs are collected in only one or two egg takes. After spawning, the eggs are slow-incubated in chilled water until ponding of fry in starter tanks occurs in February. Once removed from the incubators, fry are reared in hatchery water of near-uniform $50^{\circ} \mathrm{F}$ temperatures. As growth warrants, the fry are transferred from the circular starting tanks to Burrows ponds. The fingerling are marked in July and split into additional raceways. All hatchery fingerlings are either tagged or tin-clipped to identify them at return as hatchery spring chinook adults. Under the present rearing plan, coded-wire tags are inserted in 120,000 of the total smolt production for research and harvest monitoring purposes. Additional tagging will occur with the proposed studies affiliated with the monitoring and evaluation program. 


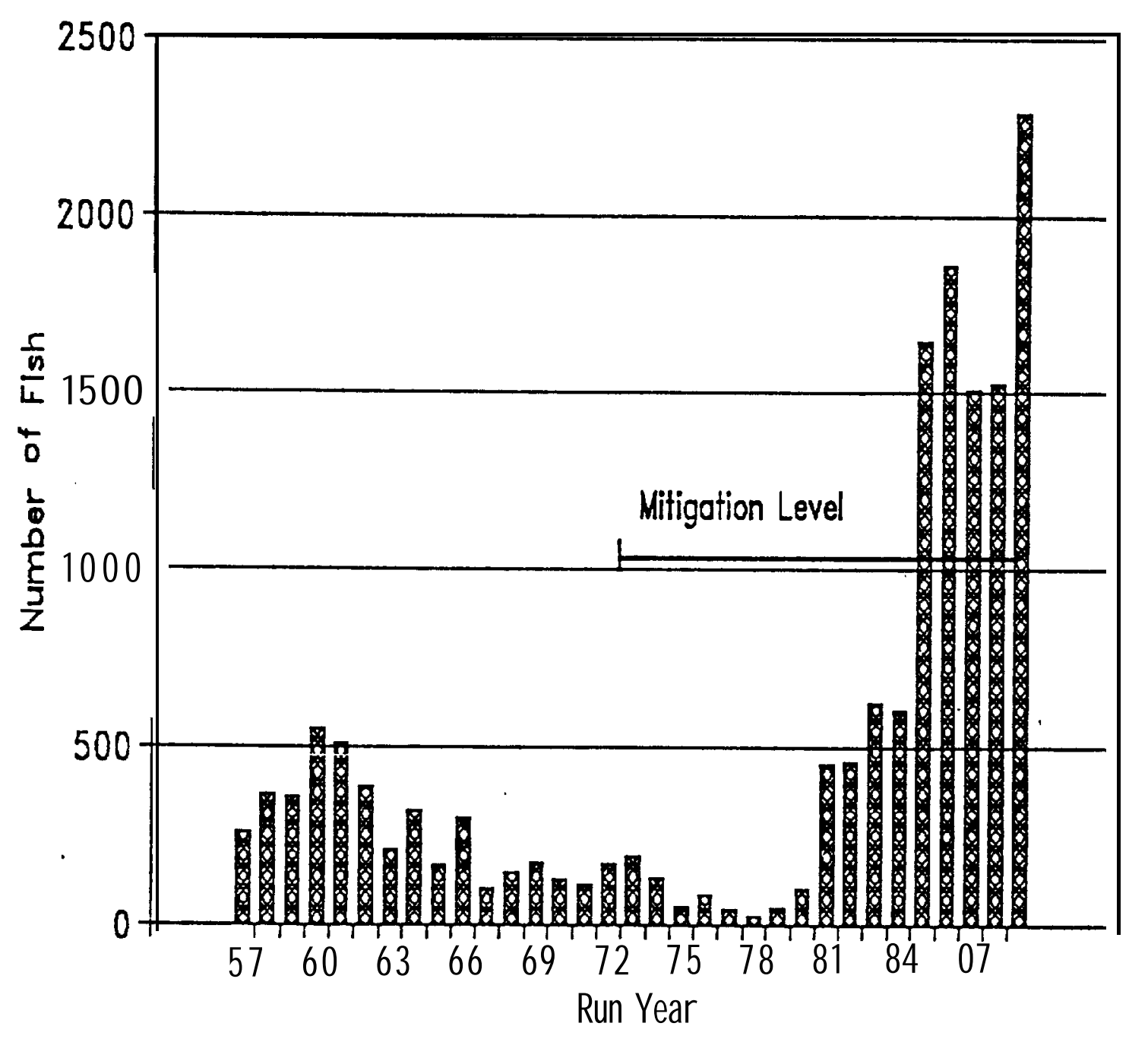

Figure 1. Returns of adult chinook to Pelton Ladder, 1957-1969. 
Two different scenarios are used during final rearing in the $\mathrm{RBH} / \mathrm{Pelton}$ Ladder production program. Eighty percent of the juvenile spring chinook $(210,000)$ are transferred to the ladder in November to rear over winter. To accommodate substantial increases in production, hatchery pond limitations dictate transfer of the additional fish to the ladder earlier than November. An experimental approach to determine successful ladder transfer time, which is dependent on C. Shasta infectivity levels, will be undertaken in the monitoring and evaluation program. Ladder transfers could occur as early as late July as net pen studies have revealed a mortality rate of less than 5 percent at this time (Lindsay and Jonasson 1987).

This plan proposes increasing the capacity of the ladder by an additional three cells above the presently used three-celled section. Current ladder density of $0.4 \mathrm{lb} / \mathrm{cu} \mathrm{ft}$ and loading of $7.3 \mathrm{lb} / \mathrm{gpm}$ (Lindsay et al. 1989) is reduced from rearing conditions at the hatchery (1.4 Ib/cu ft density and 6-8 lb/gpm loading at terminal stocking).

Ladder-reared fish are hand fed once daily, five days a week. Invertebrates originating from Lake Simtustus and within the 3-mile-long ladder may supplement the hatchery diet. Targeted release size for ladder-reared smolts is $9 \mathrm{fish} / \mathrm{lb}$, which is smaller than their hatchery-reared counterparts (about 6 fish/lb). Ladder-reared smolts appear silvery and healthy at release, which may be a result of reduced rearing density and natural food availability in Pelton Ladder.

It is unknown how many smolts stocked in the ladder survive to emigrate. The long-term survival rate expressed for ladder-reared smolts is based on the assumption that all smolts stocked in the ladder will survive to emigrate volitionally when barriers are removed in April. If, for some reason, smolts stocked in the ladder experience undetected losses during the rearing phase, the actual average rate of survival may be much higher than the expressed 1.6 percent.

A pre-liberation pathology check was first applied to ladder-reared smolts in 1989 by chumming and netting a 30-fish sample. These fish proved to be healthy and IHN-free (Rich Holt, ODFW, personal communication). Based on these results, refinement of the fish sampling method in the ladder will be conducted to permit monitoring of growth and health of size-controlled groups throughout the ladder rearing phase. A final virus check, conducted 30 days prior to release, will determine whether these fish are healthy and potential subjects for outplanting to other Columbia River subbasins.

Ladder-reared smolts are allowed to migrate volitionally as yearlings in April, the second spring after egg-take. Volitional release occurs as orifice gates are opened to each of the three ladder cells and smolts migrate out of the ladder unrestricted. Current release dates (mid-April) are based on. evaluations of release time on survival, and are timed to occur when C. Shasta levels are negligible. In mid-April, Deschutes spring chinook smolts have been demonstrated both behavioral and physiological readiness to migrate, and consequently move out of the ladder quickly. Approximately 95 percent of the smolts leave the ladder within 8 hours (Bill Nyara, ODFW, personal communication). Arrival times of smolts from RBH/Pelton Ladder at The Dalles Dam has ranged from several days to several months (ODFW 1989), with a median passage at the dam occurring l-3 weeks after release (Lindsay et al. 1989). Fast migration out of the Deschutes River is desirable, since slow-migrating smolts may cause unwanted interactions with naturally produced fish that inhabit the river.

The remaining 20 percent of the spring chinook production $(60,000$ juveniles) are reared at $\mathrm{RBH}$ and releases in the spring at the same time as the ladder-reared smolts. Hatchery smolts are crowded, pumped into a liberation tanker, and trucked for release immediately below Pelton Regulating Dam. They serve as a control for the ladder-reared test fish. A sample of hatcheryreared smolts is given a last pathology examination, including a culture for viral diseases, 30 days prerelease. Release is contingent upon results of this examination. 
New methods and strategies to accommodate increases in production will include modifications to the ponding program at the hatchery; improvements to the water-delivery system to one rearing pond at $\mathrm{RBH}$; and modifications to the ladder to isolate the current production smolts from proposed production smolts. In addition, improved methodologies will be developed to monitor growth and health of smolts rearing in the ladder, and project personnel will develop effective methods to collect smolts from the ladder to facilitate any proposed outplanting operations. Monitoring and evaluation studies will assess effectiveness of new production strategies such as alternate target size at release, and effects of altering transfer time from $\mathrm{RBH}$ to the ladder.

In the interest of maintaining genetic integrity of the $\mathrm{RBH}$ broodstock, this plan suggests changes in the broodstock acquisition, spawning and rearing practices. In addition, the TWG will further investigate recommendations for operations of "model hatcheries" (Kapuscinski 1991) and incorporate the elements that are deemed feasible and appropriate into the RBH rearing program.

\section{Broodstock Management and Acquisition}

Additional spring chinook juveniles to be raised in Pelton Ladder will be derived from broodstock collected at Pelton Ladder. From a genetic and disease perspective, Deschutes River spring chinook stock is currently the only acceptable stock to release in the Deschutes River. RBH broodstock descended from a small parent stock of Deschutes spring chinook salmon collected at Sherars Falls in the early 1970s, presumably destined to spawn in the Warm Springs River or Shitike Creek. Broodstock needs have been met from returns to Pelton trap since 1981. More spring chinook salmon have returned to Pelton trap than have been needed for broodstock since 1985. It is believed that these increased returns are the result of improved hatchery practices (including the finish-rearing of smolts in Pelton Ladder) and production of more smolts.

Collection, holding and spawning of broodstock for additional ladder-reared fish will generally follow the current procedures at $\mathrm{RBH}$ with some modification. Spring chinook salmon adults return to Pelton trap from late April to the end of July. After July 1, no unmarked adults are collected for use as hatchery broodstock. This prevents inadvertent inclusion of natural fall chinook salmon. Broodstock are selected from throughout the run proportionate to their abundance to maintain diversity in the time of return. Approximately 300 adults and 30 jacks are currently retained for broodstock from fish returning tc Pelton trap to produce the existing 270,000 smoltrelease program. Thus, each increment of 63,000 smolt production (the approximate rearing capacity of one cell in Pelton Ladder) will require collection and holding of an additional 70 adults and 7 jacks. By use of this measure, an additional 210 adults and 21 jacks would be needed to supply enough eggs to accommodate an additional section of ladder with three cells each capable of rearing 63,000 additional smolts. Existing returns could easily satisfy the added broodstock needs since at least 500 adults have returned to Pelton trap each year since 1983.

Hatchery personnel attempt to hold equal numbers of male and female chinook for broodstock, but visual differentiation of sex is difficult. Females typically comprise $70 \%$ of the broodstock take. To achieve a closer 1:1 male to female spawning ratio, we will refine our ability to visually distinguish sex. We believe this will result in the collection of equal number of males and females.

To reduce the incidence of BKD in progeny, broodstock are initially injected with erythromycin at the trap at time of collection and again in the holding ponds in early July. Erythromycin-injected fish not used for broodstock are destroyed. Returns of adult spring chinook to Pelton trap above broodstock requirements are not injected, but provided to the CTWS. 
Broodstock are kept in holding ponds at the hatchery until spawning occurs in late August or early September. An attempt is made to control fungal infections with periodic formalin treatments. Holding pond capacity is much greater than the 300 adults and 30 jacks currently being held and could easily accommodate sufficient additional broodstock to produce another 23,000 pounds of smolts. In the past, sperm from one male fertilized the eggs of three females. Beginning in 1990, sperm from one male was used to fertilize eggs from one female, and this will be the spawning ratio employed in the future. Average fecundity per female is about 3,400 eggs (Lindsay et al. 1989).

About 23 percent pre-spawning loss of females in the holding ponds is expected. All surviving females will be spawned, and more eggs are expected to be collected than are required. Eyed eggs will be reduced to 25 percent above smolt-release goal to account for expected normal rates of loss during the rearing process.

In the event adult returns to Pelton trap drastically decline and total broodstock needs are not met, as many female and male spawners would be taken at the Pelton trap and a production shortfall will be allowed to occur. Obtaining broodstock from WSNFH is impractical as that hatchery operation periodically experiences broodstock shortfalls. Additional take of broodstock from Sherars Falls is also a poor alternative as many of those fish are destined for the WSNFH. Shortages at Pelton trap are usually not determined until most of the spring chinook run has passed the falls.

If a broodstock shortfall should occur, fulfilling PGE's mitigation responsibility will be the first priority. The Pelton Ladder TWG regards production required to either conduct study requirements, or produce fish for outplant as a secondary priority to meeting PGE's mitigation requirements.

Although possible, broodstock shortages at $\mathrm{RBH}$ are an unlikely occurrence. More than 500 spring chinook have been collected at Pelton Ladder each year since 1983, and returns of adult fish over the five-year period, 1985 through 1989, have ranged from 1,151 to 1,607. In 1990, more than 2,000 adult spring chinook returned to Pelton Ladder.

\section{Production Profiles}

The goals for the Pelton Ladder project include the need to evaluate the effectiveness of the expanded rearing in Pelton Ladder. Broodstock needed for the expanded production will initially be collected in the same manner as PGE-funded production broodstock. Supplementation plans for rearing and release of out-basin stocks may eventually dictate that this fraction of the production be obtained from broodstocks more closely adapted to locales of the recipient subbasin. Processes will be identified to obtain appropriate outplant broodstocks, and care must be taken to avoid release of this exotic stock into the Deschutes River.

Currently, eggs are taken in one or two separate egg-takes in late August/early September. Additional egg-taking effort will probably be required to accommodate the desired production increases. One male will be used to fertilize the eggs of one female. The standard hatchery procedure immediately after egg-take and fertilization is to water harden and disinfect the eggs for 10 minutes in a $10 \mathrm{ppm}$ iodophor solution. Eggs of spring chinook salmon are placed in Heath incubators and slow-incubated in chilled $41^{\circ} \mathrm{F}$ water to retard development and delay ponding. This strategy has been developed by previous hatchery evaluation to yield a smelt-sized juvenile at 18 months, as desired. 
After approximately 65 days of slow-incubation, the eggs eye-up and are shocked and sorted to remove dead and blank eggs. Hatching occurs about 45 days later. Fry are incubated in chilled water until ponding. Although the existing chilling facilities at RBH can be expanded somewhat to handle short-term increases in incubation requirements, incubation of additional eggs and fry will, in the long term, require the installation of an additional chiller at the hatchery.

Ponding occurs in February when the hatched fry are moved from the Heath incubators into circular starting tanks. After transfers from circular starting tanks to Burrows ponds, the juveniles are marked (fin-clipped and coded-wire tagged) in July and a subsequent transfer of fish to Pelton Ladder occurs in November at a size of $15 \mathrm{fish} / \mathrm{lb}$. Terminal loading $(6-8 \mathrm{lb} / \mathrm{gpm})$ and density $(1.4 \mathrm{lb} / \mathrm{cu} \mathrm{ft})$ at the hatchery are currently calculated based on production goals of 30,000 fish per pond at 6 fish/lb (Table 1).

Table 1. Comparison of selected rearing conditions for juvenile spring chinook salmon in Pelton ladder and in Round Butte Hatchery.

\begin{tabular}{|c|c|c|}
\hline $\begin{array}{l}\text { Rearing } \\
\text { condition }\end{array}$ & Ladder & Hatchery \\
\hline Density & $0.4 \mathrm{lb} / \mathrm{cu} \mathrm{ft} \mathrm{f}^{\mathrm{a}}$ & $1.4 \mathrm{lb} / \mathrm{cu} \mathrm{t} \mathrm{t}^{\mathrm{b}}$ \\
\hline Loading & $7.3 \mathrm{lb} / \mathrm{gpm}^{\mathrm{a}}$ & $6-8 \mathrm{lb} / \mathrm{gpm}^{\mathrm{b}}$ \\
\hline $\begin{array}{l}\text { Water temperature } \\
\text { (November-April) }\end{array}$ & Variable, $40^{\circ}-55^{\circ} \mathrm{F}$ & Constant, $50^{\circ} \mathrm{F}$ \\
\hline Food & $\begin{array}{l}\text { Oregon Moist Pellet } \\
\text { supplemented with } \\
\text { natural food }\end{array}$ & Oregon Moist Pellet \\
\hline Migration & $\begin{array}{l}\text { Volitional--individual } \\
\text { timing, no handling } \\
\text { stress }\end{array}$ & $\begin{array}{l}\text { Trucked below } \\
\text { reregulating dam }\end{array}$ \\
\hline
\end{tabular}


To accommodate the extra rearing population when hatchery pond space becomes limiting in the fall, a program of early transfer to the ladder will be instituted. Potential for Ceratomyxa Shasta infections will be evaluated by determining a safe date of transfer to Pelton Ladder.

In previous studies which exposed liveboxed fish to ladder water, spring chinook mortality due to C. shasta was higher for fish transferred in June than for those transferred after mid-July. These mid-July transfers consistently exhibited mortality levels of less than 5 percent (Lindsay and Jonasson 1987). Based on the results of these studies and those of Ratliff $(1981 ; 1983)$, the researchers concluded that in most years, mortality is low enough in the ladder by late July to rear spring chinook salmon. This plan proposes a September transfer, which should result in negligible loss due to $\mathrm{C}$. shasta. Ratliff also indicated that chinook salmon may develop some resistance to the sporozoan's infective stage and that overall levels of C. Shasta may be declining in the reservoir and river over time.

Juveniles transferred to the ladder rear until the following spring when orifice gates are removed and the smolts emigrate volitionally in April. In the ladder, juveniles are reared in water with a temperature range of 40 to $55^{\circ} \mathrm{F}$. Fish are fed once/day, 5 days/week with Bio-Moist Pellet. Feeding is believed to be supplemented with natural food produced in Pelton Reservoir and in the ladder.

Identical numbers of smolts are currently stocked in each cell. As loading density may be a critical factor in determining survival, equal terminal loading densities will be maintained in all test and control cells, although fish numbers may vary considerably as the requirements of monitoring and evaluation investigations. Facility limitations preclude simultaneous testing of both smolt size and stocking density on survival of smolts reared in the hatchery and ladder. Proposed new production fish would be reared in an isolated section immediately above the current production section. Water from the upper section will be diverted away, rather than passed through the lower section, as a disease-prevention and water-oxygenation practice.

Due to the open system of water exchange in the ladder, treatment for diseases requiring immersion bath is generally impractical. A high-priority activity for biological personnel assigned to this project will be to develop an effective method of periodically sampling the smolts rearing in Pelton Ladder for pathology and growth assessment. Fish in the ladder are sampled during outmigration to ascertain size and tag retention rates.

The target size for release of ladder-reared smolts is currently 9 fish/lb Variations of this production goal will be evaluated through the monitoring and evaluation program to determine the best target size for maximizing survival. Based on previous evaluation results, the new section of ladder will have the capability to produce about 25,000 pounds of good-quality smolts.

Smolts are released as yearlings in mid-April when weir gates are opened to each ladder cell and the fish migrate unhandled from the ladder. Spring chinook salmon released from $\mathrm{RBH}$ and Pelton Ladder return primarily as age- 4 adults. The ladder reared fish have most often returned at a higher rate than the spring chinook reared in the ponds at $\mathrm{RBH}$ (Table 2, Figure 2). However, since smolts have not been counted or weighed out of the ladder cells at time of release, survival rates of the ladder-reared fish have been calculated based simply on numbers of tagged fish stocked in the ladder in November. If ladder-reared smolts actually experience some unaccounted level of mortality while rearing in the ladder, the actual survival rate from released smolt to adult could be much higher than indicated. 
Table 2. Mean percent return of spring chinook to Deschutes River fisheries and to Round Butte Hatchery by experimental group.

\begin{tabular}{|c|c|c|c|c|c|}
\hline \multirow{2}{*}{$\begin{array}{l}\text { Experimental } \\
\text { group }\end{array}$} & \multirow{2}{*}{$\begin{array}{l}\text { Number of } \\
\text { brood years }\end{array}$} & \multirow{2}{*}{$\begin{array}{l}\text { Number of } \\
\text { releases }\end{array}$} & \multicolumn{3}{|c|}{ Return } \\
\hline & & & Adults & Jacks & Total \\
\hline \multicolumn{6}{|l|}{ Fast-incubated: } \\
\hline Spring subyearling & 4 & 5 & 0.03 & 0.00 & 0.03 \\
\hline Fall subyearfing & 5 & 5 & 0.06 & 0.12 & 0.18 \\
\hline \multicolumn{6}{|l|}{ Slow-incubated: } \\
\hline Fall subyerling & 5 & 5 & 0.21 & 0.07 & 0.28 \\
\hline Spring yearling & 7 & 8 & 0.35 & 0.13 & 0.48 \\
\hline $\begin{array}{l}\text { Spring yearling, Pelton } \\
\text { ladder }\end{array}$ & 5 & 8 & 1.28 & 0.35 & 1.63 \\
\hline
\end{tabular}

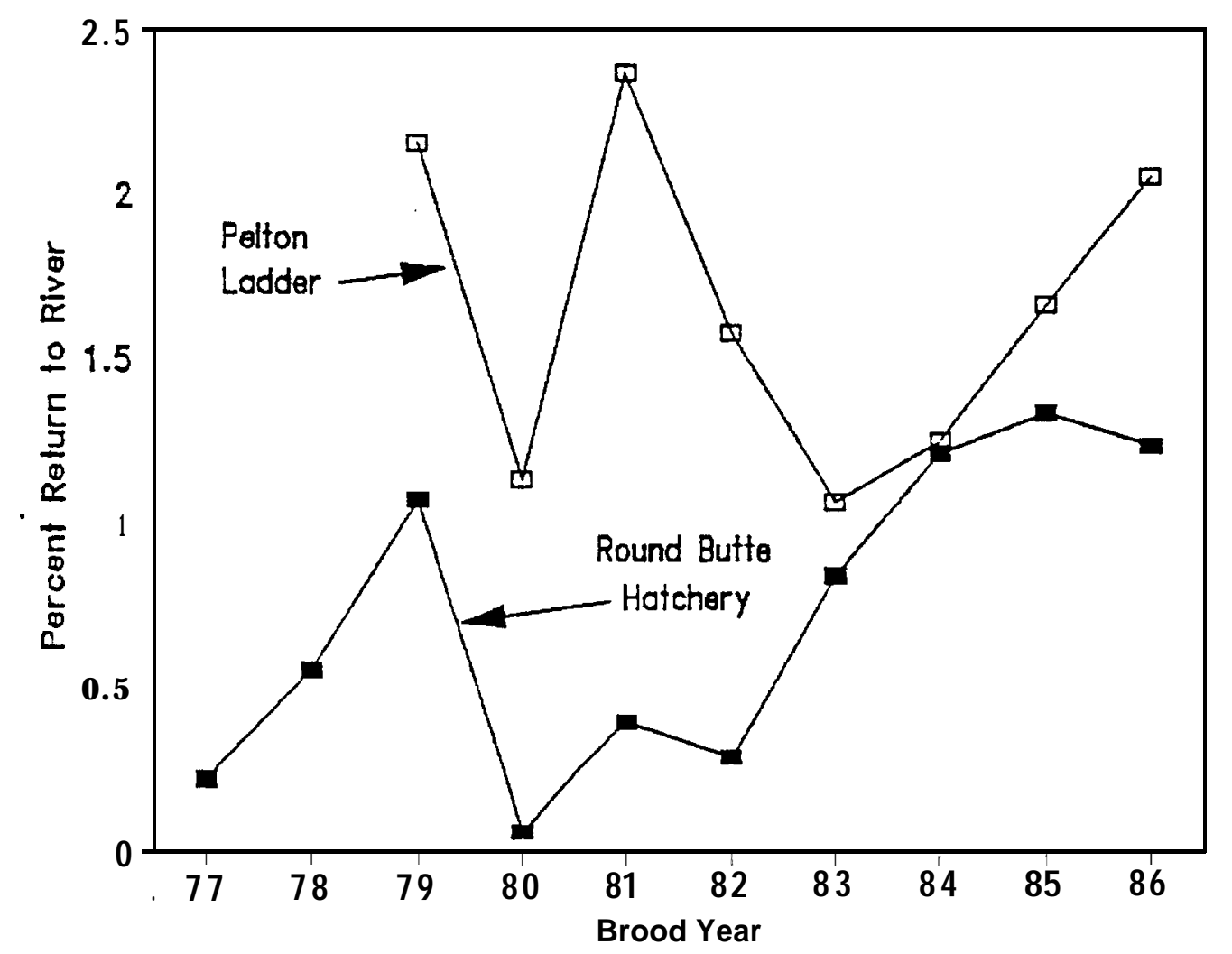

Figure 2. Adult return rate to Deschutes River from slow-incubated yearling spring chinook smolts from Round Butte Hatchery and Pelton Ladder, 1977-84 broods. 


\section{Release Strategies}

Release of the proposed spring chinook production from Pelton Ladder will follow the current strategy involving liberation of smolts as yearlings in the second spring following egg-take (18 months). Previous releases of ladder-reared subyearlings (spring chinook in the first spring following egg-take) proved unsuccessful as these fish had survival rates of less than 0.01 percent (Lindsay et al. 1989). Previous fall releases of subyearlings exhibited slightly higher return rates, but many of these fish appeared to remain in the Deschutes and Columbia rivers until the following spring before emigrating to the ocean. Quick migration at time of release is desirable as a means of reducing interactions between hatchery-released and naturally rearing fish.

Ladder-reared smolts are presently released at a size of 9 fish/lb. Hatchery-reared smolts often attain 6 fish/lb at time of release. The size-at-release variation, which meets existing goals for size at liberation, is a consequence of differences in feeding regimes. Different target sizes at release will be evaluated, based on smolt-to-adult survival, by the monitoring and evaluation plan.

Liberation of ladder-reared smolts occurs in mid-April when smolts are behaviorally and physiologically ready to migrate. This strategy appears to facilitate rapid emigration from the Deschutes River which serves to limit in-stream competition and results in acceptable levels of adult return. Smolts are allowed to migrate out of the ladder volitionally as orifice gates to each ladder rearing cell are opened. The majority of smolts emigrate quickly from the ladder and enter the Deschutes River immediately below Pelton Reregulating Dam at RM 100. This release location is in close proximity to Pelton trap where returning adults are collected. In mid-May, the ladder is drained, and the remaining fish are destroyed to prevent in-river interactions with non-migrating smolts. PGE-funded production and new BPA-funded production smolts will be sampled for size and pathogens prior to release. If decisions are made to outplant ladder-reared smolts, project personnel in cooperation with hatchery management will develop an effective process for loading smolts from the ladder into transport trucks.

It is envisioned that smolts identified as appropriate for outplanting would be concentrated into the lowest part of a rearing cell, pumped from this area by use of a motorized fish pump into a waiting liberation tanker, and immediately transported to the remote subbasin for liberation. This process would permit inventory of the approximate number of smolts released via displacement measurements in combination with average fish/pound sampling taken at the time of loading.

The most acceptable optional release strategy for potential supplementation is outplanting a portion of the ladder production into the Hood River (see Supplementation). ODFWs Fish Division has agreed that Deschutes River spring chinook should be used to supplant the Carson stock smolt releases currently being practiced in the Hood River Subbasin.

Release into other systems within the state would be contingent upon administrative decisions and acceptable pathology reports. Release into areas outside the state would require a consensus decision between the two states. In all cases, a check for IHN virus would be needed within 30 days prior to release. Unhandled release of supplementation smolts could not occur as these fish would be pumped out of the ladder or collected at a capture cell in the lower ladder and transported to their respective release sites. Personnel from $\mathrm{RBH}$ will develop effective methods of concentrating and loading ladder-reared smolts into liberation trucks for transport to remote release locations. 


\section{Management and Production History of Deschutes Spring Chinook}

Historically, spring chinook salmon spawned in tributaries of the Deschutes River up to Steelhead Falls (RM 128), in Squaw Creek, in the Metolius River, in the Warm Springs River and its tributaries, and in Shitike Creek. At present, spawning of the spring run chinook apparently does not occur in the mainstem Deschutes River. Natural production is now limited to Warm Springs River and its primary tributaries Mill and Beaver creeks, and Shitike Creek. All streams currently supporting spring chinook spawning are on the CTWS Reservation (Figure 3). Construction of Pelton and Round Butte Dams on the mainstem river in 1958 and 1964, respectively, resulted in a loss of natural production above these structures when facilities for passing downstream migrating juveniles proved ineffective.

Release of hatchery-produced spring chinook into the Deschutes River Subbasin was initiated in response to diminishing natural returns and as a requirement of the hydropower licence granted to PGE. Spring chinook have been released into the lower Deschutes River basin since 1967 and into the Warm Springs River since 1958.

Prior to 1972, juveniles released into the mainstem lower Deschutes River were reared at Oak Springs, Wizard Falls and Fall River hatcheries. In addition, spring chinook salmon fry and fingerlings from Eagle Creek, McKenzie, and Carson hatcheries were released into the Warm Springs River, and eggs obtained from Carson National Fish Hatchery were hatched in egg boxes in a pilot hatchery on the Warm Springs River (Lindsay et al. 1989). Since 1972, however, spring chinook released into the lower Deschutes River Subbasin were reared at either RBH or WSNFH. $\mathrm{RBH}$, operated by the ODFW, was constructed in 1972 by PGE to mitigate for losses of natural spring chinook salmon and summer steelhead above Pelton and Round Butte Dams. WSNFH, constructed by request of the Warm Springs Tribal Council and managed by the USFWS, began production in 1978. Natural and hatchery populations of spring chinook salmon are currently managed as distinct stocks in the Deschutes River system.

Estimates of spawning escapement in the Deschutes River above the Pelton-Round Butte dam complex prior to their construction varied considerably. Oregon Game Commission biologists estimated that in the early 1940s, about 5,000 spring chinook salmon migrated above the dam sites (OSGC 1949). From 1951 through 1955, the largest count of fish and redds above the dam sites was 649. This deceased to about 330 adults counted at Pelton trap in 1957-59; run years which, while not affected by dams in the Deschutes River, were subjected to heavy fisheries in the Columbia River.

Annual spawning escapement of spring chinook salmon in the Warm Springs River above WSNFH averaged 1,125 natural adults from 1977 through 1986 (Lindsay et al. 1989). Current natural smolt production capacity is estimated to be 140,125 smolts from the Warm Springs River system and Shitike Creek combined (ODFW 1987).

The mitigation requirement for $\mathrm{RBH}$ is 1,200 spring chinook salmon adults returning to Pelton trap annually. To meet this obligation the hatchery annually releases 270,000 spring chinook salmon smolts (about 35,000 lbs) from RBH and Pelton Ladder combined. Mitigation levels of adult returns have only been met since 1985 (Table 3). The spring chinook stock reared at RBH was derived from the indigenous stock of spring chinook salmon in the Deschutes River Subbasin in 1972. Additional broodstock was collected at Sherars Falls from 1977 to 1980.

The WSNFH currently produces about 700,000 spring chinook salmon smolts (60 percent of capacity) and has collected an average of 575 adults each year since it began operation in 1978 (Table 3). Design capacity of the hatchery is 1.2 million spring chinook salmon, requiring 900 to 1000 adults for full production (Lindsay et al. 1989). At present, the hatchery is experiencing difficulty building toward full production; collection of additional natural broodstock above the 


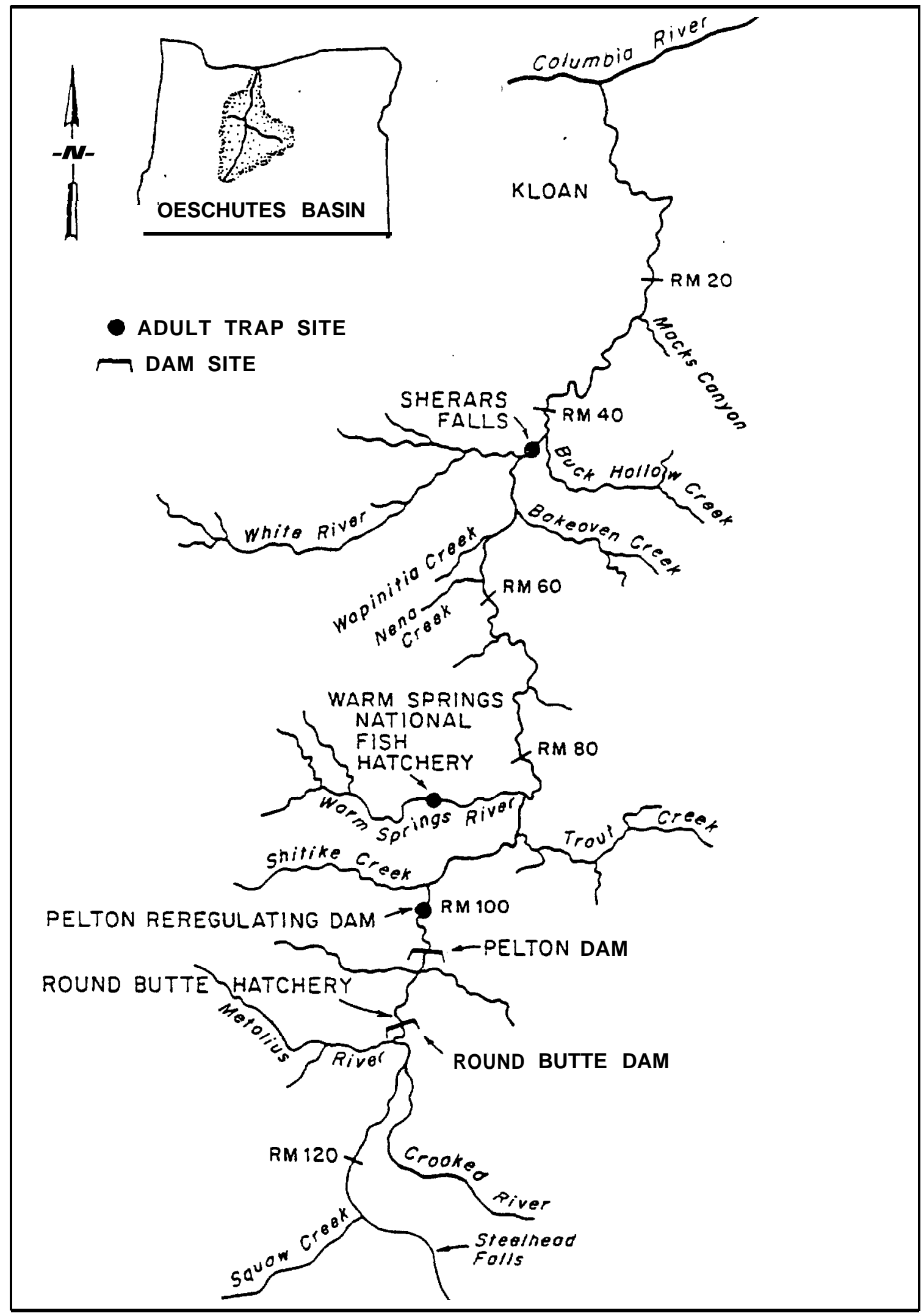

Figure 3. The Deschutes River below Steelhead Falls (RM 128). 
Tabl e 3. Run size of hatchery spring chlnook salmon (adult8 and Jacks) returning to the Deschutes River, $1977-88$

\begin{tabular}{|c|c|c|c|c|c|}
\hline \multirow[b]{2}{*}{ Year } & \multicolumn{2}{|c|}{ Herves! } & \multicolumn{2}{|c|}{ Beturn to } & \multirow[b]{2}{*}{ Total } \\
\hline & Trlbal & Recreatlonal & $\overline{\mathrm{RBH}}$ & WSH & \\
\hline 1877 & 0 & 7 & 47 & 0 & 64 \\
\hline 1878 & 0 & 0 & 24 & 0 & 24 \\
\hline $\begin{array}{l}1979 \\
1980\end{array}$ & $\begin{array}{l}0 \\
0\end{array}$ & $\begin{array}{r}0 \\
60\end{array}$ & $\begin{array}{r}60 \\
102\end{array}$ & $\begin{array}{l}0 \\
0\end{array}$ & $\begin{array}{r}\mathbf{5 0} \\
162\end{array}$ \\
\hline $1881^{a}$ & 0 & 0 & 453 & 83 & 638 \\
\hline 1982 & 138 & 522 & 463 & 916 & 2,098 \\
\hline $1884^{a}$ & 125 & 310 & 623 & 371 & 1,428 \\
\hline & 0 & 0 & 604 & 992 & 1,698 \\
\hline 1988 & $477_{C}^{\circ}$ & $\underset{C}{1,179}$ & $\begin{array}{l}1,649 \\
1,820\end{array}$ & $\begin{array}{r}1,079 \\
\mathbf{3 4 6}\end{array}$ & ${ }_{c}^{4,384}$ \\
\hline 1887 & 372 & 763 & 1,848 & 725 & 3,208 \\
\hline 1988 & 347 & 1,311 & 1,472 & 024 & 3,054 \\
\hline 1989 & 489 & 1,598 & 2,281 & 2,538 & 6. 914 \\
\hline 1990 & 425 & 1,282 & 2,266 & 1,311 & 5,283 \\
\hline 1991 & (237) & $(1,583)$ & - & & \\
\hline
\end{tabular}

a Flsheries colosed.

Because there was no creel survey of the Indian fishery, catch was estimated from the mean ratio of Indian to recreational catch In 1977-1980, 1982- 1983.

c No creel survey harvest and run size unknown.

10 percent minimum requirement (i.e. 10 percent of the hatchery broodstock will be of natural origin to help promote the retention of natural genetic traits) has been considered to reach capacity at the hatchery.

Run size of hatchery spring chinook salmon in the Deschutes River has ranged from fewer than 50 fish to about 4, 300 fish between 1977 and 1988. The larger returns in recent years are believed to be a result of increases in smolt production and improvements in rearing practices at the hatcheries. 


\section{Concerns, Uncertainties, and Solutions to Problems}

\section{Broodstock Avallabillty}

Concern: Is there sufficient broodstock available to expand production in Pelton Ladder?

Solution: There appears to be little problem. RBH has limited production capacity. Relatively few adults must be collected to meet broodstock needs. In most recent years, many more than the number of needed adults have returned to Pelton trap. These returns above broodstock needs have been provided to the CTWS. Past experiments have recycled adults through the fisheries at Sherars Falls; however, this program was discontinued when evaluation indicated few of these recycled adults were caught.

The expected doubling of the capacity of Pelton Ladder to rear salmon smolts would require a maximum addition of 210 more adults and 21 more jacks to be held at RBH as broodstock. Because many more adults are currently collected than can be used for broodstock, additional fish should be easily attainable.

Alternatives: If broodstock collection falls short at $\mathrm{RBH}$, there are options to seek CTWS approval to obtain any available adults or eggs from WSNFH, or to trap adults at the Sherars Falls fishway trap. Realistically, however, broodstock of hatchery origin are often in short supply at WSNFH and, by the time broodstock are found to be lacking at $\mathrm{RBH}$, the majority of the spring chinook run will have crossed Sherars Falls. Potential public relations problems would likely exist with taking fish from Sherars trap. Given the current abundance of returning adults to Pelton Ladder, the possibility of broodstock shortfall is a remote possibility. If broodstock numbers fail, production at $\mathrm{RBH}$ will be reduced commensurately. The Pelton Ladder TWG sets highest priority on maintaining the integrity of PGE's production program.

\section{Broodst ock Sel ection}

Concern: Is the existing $\mathrm{RBH}$ broodstock the best one to rear for project purposes?

Solution: It is believed that the existing RBH stock is appropriate. Deschutes River spring chinook, originating from broodstock trapped within the Deschutes River, have been reared and released at RBH since 1967 (Howell, et al, 1985). This stock meets ODFW and CTWS guidelines for propagation and release into the Deschutes River, and use of this indigenous broodstock avoids many of the extra genetic and disease concerns that would be associated with importation of broodstock from another river system for use in the Deschutes River.

Alternatives: Pelton Ladder could rear other stocks of spring chinook salmon or even other species. However, before such a program could be implemented, stock transfer and disease prevention guidelines must be addressed. Special facility modifications will be provided to the rearing cells to assure that stocks or species not approved for release into the Deschutes River are not inadvertently released in case of screen failure or vandalism.

The Council's Monitoring and Evaluation Group members have suggested the broodstock program at $\mathrm{RBH}$ might benefit from infusion of more wild-type genes. This would have to be accomplished in concert with WSNFH during years when wild fish returns are large enough to warrant removal of some for genetics improvement activities. 


\section{Competition and Predation}

Concern: Hatchery chinook may compete with natural resident and anadromous fish in the Deschutes River after release.

Solution: Release all chinook at smolt size, and at a time of year past studies have shown to promote rapid emigration from the Deschutes River. The preference is to prudently limit the number of smolts that will enter the Deschutes River at Pelton (our preferred management alternative is to initially increase smolt releases by 62,000 fish, pending concurrent increases in the naturally-produced component of the adult return). The management practice of externally marking all hatchery-released spring chinook smolts released into the lower Deschutes River as a method of monitoring effects of hatchery production on natural populations over time will continue.

Smolt-release practices will be identified that reduce the incidence of residualism of smolts, incidence of precociousness in the rearing populations, and return of age-2 males (subjacks). We retain the option to sample fish populations in the Deschutes River post-release to detect rates of residualism of smolts, possibility of excessive subjack returns, and any detectable changes in trout populations (numbers/unit river mile, size frequencies, and distribution). Realistically, however, these changes are difficult to quantify in field studies. We prefer to limit the number of additional smolts released. We will implement substantial increases in releases of hatchery smolts concurrent with activities in the watershed designed to increase the runs of naturallyproduced fish.

Alternatives: Rear and release only part of the production potential of the new ladder section while plans are made for increasing natural production. Outplant production from Pelton Ladder into other Columbia River subbasins identified as acceptable for supplementation. No releases of subsmolt chinook are envisioned.

\section{Genetic Concerns}

Concern: The proposed project could jeopardize the genetic integrity of resident and anadromous fish in the Deschutes River Subbasin.

Solution-Hatchery Chinook: (see Genetic Risk Analysis) Broodstock collections and rearing practices at $\mathrm{RBH}$ will be conducted in accord with guidelines for maintenance of genetic variability expressed in OAR 635-07-800, and will be improved insofar as possible (Kapuscinski 1991). A 1:1 male-to-female spawning ratio will be maintained, and hatchery personnel will work to improve sex differentiation. We will investigate feasibility of accessing more wild-type Deschutes River adults to incorporate into the broodstock at $\mathrm{RBH}$. Additional measures to maintain good broodstock practices suggested by GEM or HETWG will be incorporated into the production program at $\mathrm{RBH}$. CBF'WA will sanction the genetics guidelines applicable to conduct the study.

Alternatives: Any selective breeding practices that may be proposed for $\mathrm{RBH}$ spring chinook will undergo thorough review by agency and public interests.

Concern: Hatchery adults may stray into natural production areas and spawn with natural fish.

Solution: The practice of fin marking all hatchery-produced spring chinook smolts released into the Deschutes River will be continued. This provides the capability to visually distinguish 
returning hatchery-produced adults, and allows a variety of evaluations that could lead to remedial measures or changes in management of production or harvest.

Following are some of the specific solutions and actions identified to address the straying concern:

- Maintain external identification (fin marking) of all hatchery-produced salmon smolts released into the subbasin (RBH and WSNFH).

- Continue to survey natural production areas (Shitike Creek, lower Warm Springs River below WSNFH, and White River) pre-project and post-project to determine if rate of straying of hatchery-produced fish increases over time in apparent response to increased hatchery production in Pelton Ladder. Appearance of fin-marked fish will indicate intrusion of hatchery fish; CWT collections will indicate hatchery source or smolt-release treatment.

- Continue the program of excluding hatchery fish from the breeding population that ascends above WSNFH on the Warm Springs River. Document the proportion of RBH fish that return to WSNFH, and apparent changes in rate of straying to this location over time.

- Continue monitoring the catch of spring chinook at Sherars Falls, document the numbers of natural and hatchery fish taken, make judgements whether naturally-produced fish are being overharvested in this mixed-origin fishery. Investigate reports that a fishery for spring chinook is developing in the lower Deschutes River below the existing bait-fishing area. Use the stock-recruitment curve developed for natural production of salmon in the Warm Springs River (Lindsay, et al, 1989) as an aid in making decisions about adequacy of escapements and potential overharvest.

- The provision of smolt-acclimation and adult-collection facilities at strategic release sites to control excessive straying of returning adults was seriously considered. These facilities will be required for implementation of outplanting of Pelton Ladder-reared smolts into remote subbasins. However, construction of such facilities in the lower Deschutes River to facilitate conduct of the Pelton Ladder project substantially changes the low-capital nature of the study; similar acclimation/collection facilities recently constructed on NE Oregon tributaries have cost from $\$ 600,000$ to $\$ 2,000,000$ (Drew Schaeffer, ODFW Fish Culture, personal communication, 1990).

Alternatives: Do not increase the release of hatchery-bred salmon into the Deschutes River Subbasin.

\section{Adequacy of Existing Facilities}

Concern: Incubation-water chilling facilities at $\mathrm{RBH}$ are inadequate to make substantial increases in production.

Solution: Provide additional water-chilling facilities. Expanded smolt production could begin with the 1991 brood using existing chilling facilities, but only by making creative use of the available chilled water. We must provide $\mathrm{RBH}$ with needed incubator trays to facilitate increased incubation.

Alternatives: Incubate eggs in chilled water at another station and truck them back to $\mathrm{RBH}$ for finish-rearing. 
Concern: Early-rearing facilities at $\mathrm{RBH}$ are limited, and few ponds exist to isolate groups of tagged test and control fish.

Solution: Make accommodations to use the existing ponds in the most effective manner (shift fish-marking dates; move brown trout to unused adult pond). Limit numbers of tagged test and control groups to the number of available rearing ponds. Employ tagging studies to determine if fish started at RBH can be safely moved to Pelton Ladder earlier in the year (September) to reduce stocking density in the hatchery ponds.

Alternatives: Provide more pond space, permanent or temporary, at RBH to accommodate more test groups. Rear and tag test groups at another station and transfer them back to RBH/Pelton Ladder for finish-rearing and release (introduces test variables).

Concern: Insufficient pond space at RBH precludes isolating several broodstocks or genetic strains that may be needed for outplanting.

Solution: We have already taxed the flexibility of the existing pond space and management structure to accommodate starting the expected increase in production. We could provide temporary ponds to maintain isolation of two distinct genetic stocks. If we need to isolate more than one genetic stock in addition to the existing $\mathrm{RBH}$ stock, additional hatchery pond space will have to be provided (which markedly alters the low-cost nature of the project).

Alternatives: Rear only Deschutes stock; transfer these only to out-plant sites where Deschutes stock is acceptable donor. Start supplementation fish at another station, transfer them to Pelton Ladder for finish-rearing. Eliminate part of the production program at RBH for other species.

Concern: RBH water supply is currently taxed at times of the year, and may not support increases in production of smolts to be reared in the hatchery.

Solution: There is adequate water available; however, the delivery system could be expanded.

Alternatives: Discontinue rearing some species at $\mathrm{RBH}$ in favor of producing test fish. This is a poor alternative as PGE's mitigation production would be affected and the RBH brown trout program has state-wide trout management implications. Determine when fish can be safely transferred from RBH to Pelton Ladder via livebox tests and shipment of test groups to the ladder in September.

\section{Di sease Concerns}

Concern: Increasing production of chinook salmon at RBH/Pelton Ladder may increase the potential for disease proliferation or incidence in the hatchery facilities or in the Deschutes River.

Increasing hatchery production inevitably provides potential that more disease-susceptible individual fish will be included in the rearing population. This increases, to an undeterminable degree, the potential for disease outbreaks in the hatchery, in the ladder, or in the river. However, the water supply for $\mathrm{RBH}$ originates from naturally-filtered leakage from Round Butte Reservoir, and only very small disease organisms (such as viruses) have been found to enter the hatchery water supply. The stock of spring chinook currently propagated at the hatchery appears highly resistant to the indigenous viruses, but Deschutes steelhead are susceptible. Bacterial Kidney Disease $(\mathrm{BKD})$, once a serious disease concern at $\mathrm{RBH}$, has been controlled in recent broods by application of antibiotics as injected in pre-spawning adults and in periodic therapeutic feedings 
to juveniles. Feeding of antibiotics to juveniles was discontinued when successive broods did not test positive to $\mathrm{BKD}$. There is the option to reinstate the prophylaxis of juveniles if BKD reappears.

Ceratomyxa is present in the Deschutes River and Pelton Ladder from late spring into early summer (Ratliff, 1981; 1982). Livebox tests performed in Pelton Ladder indicated no more than 4 percent losses to ceratomyxosis when Deschutes spring chinook smolts were transferred to the ladder in mid-to-late July (Lindsay and Jonasson 1987).

Solution: Continue to inject adults with antibiotics to control BED in the adults and progeny. If BKD appears in the rearing juveniles, we will reinstate therapeutic feedings of antibiotics. Maintain loading densities in the $\mathrm{RBH}$ ponds at or below the calculated maximum densities of $14.06 \mathrm{lbs} / \mathrm{pm}$ inflow and $2.06 \mathrm{lbs} / \mathrm{cu}$. ft. volume (Tim Walters, ODFW Hatchery Practices Biologist, personal communication, April 1990). Other solutions include the following:

- A high volume of flow through the rearing ponds will be maintained, and the program of regular pond sanitation practices will be continued.

- All new construction to modify Pelton Ladder to rear more fish will include provisions of isolated water intake and discharge features; water from one section will not pass over fish rearing in a lower section (one section equals three rearing cells, each cell currently rears 70,000 spring chinook smolts).

- Fish will not be transferred to Pelton Ladder until such time fish exposed to livebox tests have been shown to be free from Ceratomyxa.

- Pathologists will regularly inspect rearing fish while they are in the hatchery and ladder. All smolts will be certified for release by ODFW Pathologists.

Alternatives: Do not increase production of chinook salmon at RBH/Pelton Ladder. Rely on studies of improved hatchery effectiveness to produce more adults from the existing level of smolts produced.

\section{Effecti veness of the Exi sti na Mti aati on Proaram at RBH Pel ton Ladder}

Concern: Facility modifications needed to expand rearing capability in Pelton Ladder may inadvertently reduce the efficiency of the successful mitigation program that has been achieved.

Solutions: Maintain the PGE-funded production program as unchanged as is practically possible (e.g., maintain existing stocking densities, time of shipment to Pelton Ladder, target smolt sizes, location of rearing in the ladder, and time of smolt release).

- As part of the M\&E studies, monitor the performance of fish rearing in Pelton Ladder as early indicators of variance from previous experience.

- As part of the M\&E studies, maintain relative measures of survival from smolt to adult.

- Absolve PGE of the responsibility for meeting adult return (not juvenile production) levels during those years that study fish are expected to return. However, increasing the production in Pelton Ladder has a high likelihood of compensating for reasonably small alterations in survivorship. 
Alternative: Consider a limited-production "shakedown" brood for rearing in the new ladder section. This would be implemented in the first year post-modification to detect major problems before full production is implemented. 


\section{PRODUCTION FACILITIES}

The spring chinook production program at $\mathrm{RBH}$ employs rearing facilities at both the hatchery and in Pelton Ladder. Expansion of production in the ladder will require minor physical modifications to the hatchery and the fish ladder. Since the intent of the proposed project is to retain the small-scale, low-capital nature of the existing artificial propagation program, no new major facilities are envisioned to meet new production goals. Facility changes and expansion needed to produce more fish would be inexpensive in relation to costs of new hatchery facilities.

$\mathrm{RBH}$, located at the base of Round Butte Dam, produces summer steelhead and spring chinook. Experimental production of brown trout (Salmo trutta) is also part of the hatchery program. Rearing facilities at the hatchery include 24 circular tanks, each 6 feet in diameter, and 10 Burrows raceways. Total incubation capacity for spring chinook salmon and summer steelhead is 1,072,500 eggs and 2,145,000 eggs, respectively, employing Heath incubators. Incubation of the present spring chinook production requires one chiller for the slow-incubation process. Two adult holding ponds, each with about 1,000 adult holding capacity, complete the existing facilities at $\mathrm{RBH}$.

Rearing water at $\mathrm{RBH}$, which totals 8,590 to $8,965 \mathrm{gpm}$, originates as naturally filtered leakage from Round Butte Reservoir (Walters 1989). Although the present water supply is taxed at specific times of the year, plenty of good-quality water is available and could be accessed if the current delivery system were enlarged. Additional rearing water is not required to accommodate the envisioned limited increases in production at the hatchery. The increased production, however, requires that changes be made in the $\mathrm{RBH}$ production plan--reducing fish density in the $\mathrm{RBH}$ ponds by transferring some of the fish to Pelton Ladder in September. This is two months earlier than the previous program (November). The Monitoring and Evaluation plan will evaluate the effects of this early transfer on survival rates of smolts produced.

Pelton Ladder is an adult fishway extending from below Pelton Regulating Dam to Pelton Dam, which impounds Lake Simtustus (Pelton Reservoir). The ladder was originally designed and constructed to pass adult chinook salmon and summer steelhead around the reregulating dam to Lake Simtustus. However, the ladder was abandoned for adult passage after facilities at Round Butte Dam, located above Pelton Dam, failed to effectively pass juvenile salmonids downstream. The majority of the ladder channel is constructed of concrete, with a small middle section remaining as earthen excavation.

The ladder is 10 feet wide, 6 feet deep, and 2.8 miles long. Cross-sectional walls are positioned in the ladder according to changes in elevation. Wall divisions with orifice openings create sections approximately 100 yards in length at the lower ladder rearing area. Generally, the lower portion of the ladder is of a lower gradient that progresses to higher gradients in the upper portion, although low-gradient areas do exist in the upper ladder. Maximum ladder flow capacity is $40 \mathrm{cfs}$. Current water flow through the ladder is $8 \mathrm{cfs}$ for propagation purposes, or 20 percent of the available ladder flow capacity. Based on the availability of low-gradient sections and flow, the ladder could potentially accommodate almost five times the existing production level (Bill Nyara, ODFW, personal communication).

Rearing in the ladder currently takes place in a modified lower 300-meter portion of the ladder, using only 6 percent of the available ladder space (which comprises about 20 percent of the low-gradient ladder capacity that appears most suitable for rearing fish). Three cells separated by drum screens comprise the rearing section currently being occupied by PGE-funded production. Juveniles are separated in these serial rearing cells by means of gated orifices and rotary drum screens positioned directly upstream from the gated walls. Water in the rearing cells is pooled when the lower bypass and orifice gates are closed. 
Accommodating the proposed increase in production will require additional rearing water in the ladder and enlarged water-chilling facilities. Although early-rearing facilities are adequate, current pond availability is limited for the purpose of isolating groups of tagged salmon smolts because of concurrent needs for marking and segregating ponds of steelhead. Since space is scarce at the hatchery, creation of additional pond space for marking PGE- and BPA-funded test groups would involve (1) modifying the unused adult holding pond to hold brown trout, (2) delaying the grading of steelhead, and (3) moving groups of tagged chinook to the ladder earlier (thus freeing up some ponds). Otherwise, engineering evaluations would be required to determine the feasibility of providing two additional ponds and appropriate water supply capable of producing 5,000 pounds of smolts to permit rearing, marking, and segregation of the needed test and control groups.

Needed ladder modifications to provide an additional 300-yard rearing section (3 cells) would include the installation of drum screens, headbox, intake and discharge piping and orifice gates. The three rotary drum screens and orifice gates would serve purposes identical to those currently employed in the existing production section. To isolate the two respective sections (BPA- and PGEfunded productions), a headbox including water-flow control structures above the uppermost section (BPA) and intake piping would divert half $(8 \mathrm{cfs})$ of the proposed ladder flow to the lowermost section (PGE). New discharge piping at the base of the upper section would allow for isolated discharge water from the upper section water to the adjacent regulation reservoir. Piping water around the upper three cells closely replicates the existing rearing strategy in each section. It will also both facilitate future experimental designs through sectional isolation, and eliminate possible water quality and disease transfer problems associated with serial passage of rearing water from the upper section over the fish rearing in the lower section.

ODFW engineers suggest using 24-inch, spiral-corrugated pipe to transport $8 \mathrm{cfs}$ of flow from the proposed headbox to the lower rearing section. Sufficient head to drive that amount of flow would be provided by weirs installed in the headbox. Provision of a total $16 \mathrm{cfs}$ of flow would be required to finish-rear both production sections from September to April.

Other miscellaneous modifications needed for the project include (1) extension of the roadway along the east side of the new ladder section, (2) installation of stairs, gripstrut walkway and handrails at each new drum screen, and (3) installation of water-level alarms in each ladder section. 


\section{SUPPLEMENTATION PLANS}

\section{Release Sites}

All spring chinook smolts reared at $\mathrm{RBH}$ and Pelton Ladder as part of the hatchery effectiveness studies will be released at a standard site to limit variability in test results. The standard site is adjacent to the exit to Pelton Ladder.

\section{Supplementation Opportunities and Constraints}

Smolts reared in Pelton Ladder could be outplanted to other Columbia River subbasins, thus making effective use of the rearing capacity of the ladder, reducing potential for interactions between natural and hatchery fish within the Deschutes River Subbasin, and contributing to goals for adult return to the Columbia River.

Potential in-basin release sites include natural production areas above the Pelton-Round Butte Dam complex and the White River above White River Falls. Potential recipients outside the Deschutes River Subbasin may be identified by the systems planning process, but Northeast Oregon Fish Project planners have expressed interest in supplementing spring chinook returns to the Hood River system. ODFW's Fish Division has approved this concept.

Determining natural production potential and acceptable release areas for spring chinook above the Pelton-Round Butte Dam complex would be undertaken only if a study indicated fish passage was feasible. If technically feasible, proposed development of upstream and downstream passage past the Pelton-Round Butte hydroelectric complex could possibly re-establish anadromous fish production above Round Butte Dam. However, new technology for collecting and passing downstream migrants would have to be developed and proven effective.

Historically, spring chinook spawned in Deschutes River tributaries as far as Steelhead Falls (RM 1281, Squaw Creek and the Metolius River. Although access to substantial spawning areas has been blocked by the dams, spawning in tributaries may be a viable alternative.

Supplementation would be designed to develop, in the long term, a sustained natural population. Extensive monitoring and evaluations would be required to determine if supplementation was successful, and the impacts of anadromous fish on resident species once production was established.

Outplanting a portion of the extended ladder production into the White River above White River Falls, to eventually establish a natural run of spring chinook salmon, would follow approval and implementation of the proposal to provide passage facilities at the falls (ODFW et al. 1985). Passage of adult spring chinook salmon above White River Falls (and concurrent juvenile bypass below) is an action plan recommended in the Deschutes River Subbasin Plan. This project, under review by CTWS and Oregon Fish and Wildlife Commission, would provide access to 100 miles of spawning and rearing habitat that is currently unavailable. Outplanting ladder-reared smolts in upper White River, coupled with effective passage facilities at White River Falls, may initiate a new run of naturally sustained spring chinook salmon.

Outplanting ladder-reared spring chinook into the Hood River system as part of the Northeast Oregon Fish Project is a viable option if pre-liberation examinations revealed the production to be IHN-free and the transfer concept met administrative approval (Rich Holt, ODFW, personal communication). The draft Genetic Risk Assessment for Hood River (Cramer 1991) concluded 
that the native Hood River stock of spring chinook became extinct in the mid-1960s, and that use of Deschutes stock for re-establishing runs in this stream has certain advantages. Current short-term hatchery supplementation of 150,000 spring chinook salmon smolts from Carson stock was initiated in 1988 as part of US vs Oregon agreements. This release was determined to be sufficient both in the short term and the long term to fully seed available spring chinook habitat (ODFW 1989).

Carson stock is currently used in the Hood River because, at the time of project inception, this stock represented the best choice based on availability and disease constraints. Spring chinook smolts are currently released into the West Fork of the Hood River where spawning and rearing is assumed to occur. Spawning and rearing may also occur in Lake Branch Creek and the mainstem Hood River (ODFW 1989).

$\mathrm{NEOH}$ planners have suggested it would be advantageous to convert to the release of Deschutes stock in the Hood River system, which currently receives Carson stock spring chinook smolts. This conversion would likely result in higher survival rates. The Hood and Deschutes rivers are situated in reasonably similar geographic areas. Implementation of this strategy would provide a productive use for the excess Deschutes stock spring chinook smolts expected to be produced in Pelton Ladder. It would, however, require developing (1) methods for sampling ladder-reared fish for pre-liberation pathology examinations, (2) methods for collecting, loading and hauling the ladder-reared smolts, and (3) adult trapping and holding facilities somewhere in the Hood River system.

Although providing smolt acclimation facilities in the Hood River system may reduce the incidence of adults straying back to the Deschutes River, it would also reduce the time smolts are reared in Pelton Ladder (one of the advantages identified to expanding rearing in the ladder). $\mathrm{NEOH}$ planners currently envision providing acclimation facilities for half of the outplanted Deschutes stock. Subsequent evaluation of the effects of this acclimation approach, based on relative survival rates, would dictate future needs to expand or eliminate the acclimation program.

Currently, Hood River spring chinook are harvested by sport anglers in the Hood River steelhead fishery and in the Columbia River sport, commercial, or tribal subsistence and ceremonial fisheries. Enhancement of the depressed Hood River spring chinook stock would provide harvest opportunities for sport, commercial, and tribal fisheries in the Columbia River and for sport and tribal fisheries in the Hood River (ODFW 1987).

With all options for supplementing natural spring chinook populations, infusion of natural genes into the hatchery broodstock may increase survival potential of hatchery stock in the wild, thereby benefitting supplementation potential, and helping to maintain genetic integrity of the existing natural stocks.

The option is also available to rear foreign stocks in the ladder and subsequently release these smolts back into their respective subbasins. To employ this program, specific criteria would need to be met, including (1) incubation and early-rearing in clean water as a measure against development of viruses, (2) installation of a fail-safe system to prevent accidental release of foreign juveniles into the Deschutes River, (3) pre-liberation virus checks, and (4) approval from appropriate administrative authorities. Acquired broodstock (e.g., Hood River stock, Carson Hatchery) and their progeny would receive injections and therapeutic feedings of antibiotics if necessary. Juveniles would be finish-reared in an isolated ladder section and pumped out for transfer and release into respective outplanting areas. 


\section{Genetic Risk Analysis}

This section discusses the genetic implications that fishery managers have considered both in development of the Pelton Ladder Master Plan and in defining the associated management preferences. All management actions taken in the Deschutes River include a measure of risk to the genetic resources that exist in the stream and its tributaries. In order to make prudent decisions, managers and fish culturists attempt to carefully calculate as many costs and benefits of the proposed management intervention as possible, and base their decisions on informed risks that are deemed to have, in the predominance, favorable effects. Oregon's Wild Fish

Management Policy and Natural Production Policy dictate that all possible precautions be taken to prevent loss of genetic resources in native fish stocks.

The Council has shown support for genetics conservation. A formal procedure for assessing relative risks to genetic resources has not been perfected, but substantial preparatory and explanatory information has been published (Riggs 1990). The Columbia Basin Fish and Wildlife Authority's Integrated System Plan (1990) and Busack (1990) have identified, in combination, four primary types of genetic risk (discussed in greater detail in Cramer 1991). More recently, the Council's Monitoring and Evaluation Group, in consultation with geneticists, have published a draft array of "genetic yardsticks" as relative measures against which to compare the effects of human intervention in fish population genetics:

- Movement toward extinction, or the total loss of a population. This usually occurs through processes of overharvest or massive losses or alterations of natural habitats (often as the result of man's activities).

- Losses of within-population genetic variability, primarily as the result of changes in selection pressures or genetic drift. These can occur either in natural habitats or in a hatchery, but is particularly critical when effective population sizes are small.

- Interbreeding, similar to losses of genetic variability as the result of genetic influences resulting from factors outside the population of concern, such as which occur when populations become mixed. These changes result in the loss of unique genetic attributes intrinsic to locally-adapted populations.

- Artificial selection usually occurs when fish are subjected to selection pressures, either intentional or inadvertent, in a husbandry facility.

ODFW's Natural Production Program is currently developing an "expert system model," which will provide managers with a consistent and systematic approach for expressing genetic risk analyses. In the interim, ODFW's Staff Geneticist has provided a systematic flow process for identifying potential genetic risks associated with various management interventions (Kathryn Kostow, ODFW, personal communication, July 1990). In order to comply with guidelines established by Oregon's Wild Fish Management Policy and Natural Production Policy, ODFW recognizes a modified, and somewhat more detailed and comprehensive, array of mechanisms of genetic change: selection pressures, genetic drift and inbreeding, gene flow or migration, and mutations and chromosomal rearrangements.

Selection Pressures may include any aspect of the natural or hatchery environment, including competition or predation caused by other populations, that result in differential reproductive success. Genetic change occurs as the genetic variation contained in some individuals is passed to decedents while that contained in other individuals is lost. Selection pressures serve to increase the average fitness of the population. However, as selection pressures change over time, the 
population must adapt to the changes to remain productive. If the population loses this adaptability, it may become extinct.

Genetic Drift and Inbreeding are processes that cause random genetic changes in a population. In small populations, these processes may reduce both genetic variations and average population fitness as individuals and the genetic variation they carry are lost at random.

Gene Flow or Migration is the process by which individuals born in one population both migrate to and breed in another population. The genetic variation carried by the migrants is incorporated into the receiving population (and lost from the source population). Gene flow is an important source of new genetic variation for a population. However, it can also decrease average population fitness if the migrants are less fit in their new environment than are the original members of the population.

Mutation is genetic change caused by base substitutions in DNA and is the ultimate source of new genetic variation. Chromosomal rearrangements are genetic changes caused by inversions, deletions and translocations of segments of chromosomes. These changes are important in the reproductive isolation of populations and in the ultimate development of new species.

All of the mechanisms of genetic change are natural processes in evolution. Mankind produces a genetic risk when he alters the manitude or the rate of the processes in such a way that populations lose current reproductive capacity or the potential for evolutionary adaptation.

To adequately express the genetic risks inherent in fisheries management decisions, these risks must be related to the fish populations being managed. The populations of Deschutes River spring chinook currently recognize are, at least:

1. The RBH chinook--regarded as a domesticated strain that have been cultured over time in RBH and Pelton Ladder. This population, initiated in 1972 from adults collected in the Deschutes River, has the attributes of being well-adapted to the rearing regime in our artificial propagation facilities; appears to maintain good isolation from natural spawning areas in the lower Deschutes River Subbasin; and has (after substantial effort) developed into a hatchery-adapted fish that survives well and returns at very respectable rates as adult fish to the Deschutes River.

2. Naturally producing spring chinook of the Warm Springs River system--represent the strongest enclave of naturally spawning Deschutes River spring chinook. Adults must pass the sorting facilities at WSNFH (RM 8 on the Warm Springs River) to access the natural spawning areas. Therefore, these fish probably have received the least amount of gene flow from hatchery-produced salmon. Through the sorting process at WSNFH, these fish are reproductively isolated from the impacts of hatchery fish.

3. Wild spring chinook of Shitike Creek--a small population of naturally producing fish which, based on spawning survey data, has received only a limited amount of gene flow from hatchery populations.

4. Hatchery spring chinook produced by WSNFH--although domesticated, this population receives annual infusions of gene flow from naturally produced fish and retain the more protracted spawning period characteristic of natural populations of Warm Springs spring chinook.

Other fish populations that must be considered include the anadromous and resident fish species that inhabit the mainstem Deschutes River below Pelton Regulating Dam, and the resident fish that exist above White River Falls. Anadromes in the mainstem Deschutes include summer-run 
steelhead (both wild and hatchery populations), wild, fall-run chinook salmon, a vestigial run of sockeye salmon, and a substantial run of Pacific lamprey that comprises an important food item to native Americans. Coho salmon were introduced to the Deschutes River at one time, and remnants of this population may survive. Biologists speculate that the chinook crossing Sherars Falls in June and July may include a summer-run component.

Several species of resident game and nongame fish (U.S. Bureau of Land Management 1985) may be affected by management interventions imposed by implementation of the Pelton Ladder project, including a redband trout population in the mainstem Deschutes River that is nationally recognized for its aesthetic, economic and recreational values. Although the populations of bull trout in the lower Deschutes River are not well understood, it is known that large populations occur in the upper Warm Springs River and in Shitike Creek, and some inhabit the mainstem of the river. These fish deserve special management consideration.

Based upon comparison of allele frequencies, the rainbow trout of White River above White River Falls appear to be different from the mainstem Deschutes rainbow. The White River rainbow are isolated from the populations of trout in the mainstem Deschutes River by White River Falls.

Since some of the potential uses of fish reared in Pelton Ladder include transporting smolts to other subbasins, the resident and anadromous fish of those streams are also potentially affected. The NE Oregon Fish Project will both select the specific outplant recipient basin and prepare an appropriate genetic risk analysis for that proposed management intervention. NEOH planners currently propose transporting part of the Deschutes stock smolts reared in Pelton Ladder to the Hood River for release, and a draft genetic risk analysis has been prepared (Cramer 1991).

The possibility exists to import out-of-basin fish stocks to rear in Pelton Ladder for eventual transport back to the subbasin of origin. In that instance, there is a need to provide facilities in Pelton Ladder to prevent the accidental release of these exotics into the Deschutes River, and also the development of smolt acclimation facilities at the release site to reduce the possibility of straying back to the Deschutes River.

As envisioned in the monitoring and evaluation plan, three additional rearing cells would be created in Pelton Ladder. These cells would add 187,000 (23,331 pounds) RBH-origin spring chinook smolts to the current production. Following are the management alternatives identified for the use of these fish, and the genetic risks associated with each of these alternatives:

\section{Alternative 1. Release all these new-production smolts into the Deschutes River in the vicinity of Pelton Ladder.}

\section{This action would:}

Increase harvest (man-controlled predation) in response to the increased hatchery production. Harvest of naturally produced spring chinook would likely increase proportionately, representing a change in selection pressures (which could result in movement toward extinction and increase the opportunity for loss of within-population genetic variability should the size of natural fish populations become sufficiently reduced). This effect could possibly be moderated by selectively harvesting only hatcheryproduced fish, since all unmarked chinook in the river are presumably naturallyproduced fish. The significance of this potential effect is reflected by constraints stated in the Deschutes Subbasin Plan, which specifically preclude increases in smolt releases of this magnitude in the absence of corresponding increases in natural production of spring chinook in the subbasin. 
Increase gene flow from hatchery populations to natural populations, thus increasing the risk of interbreeding, with risk elements of natural selection. As more hatchery-origin chinook return to the Deschutes River Subbasin, it is possible that the number migrating into natural populations may also increase. The extent of this interchange depends, in large measure, upon how reliably the hatchery adults home to a collection facility. The degree and trend of this interchange will be monitored by systematically observing the incidence of marked (hatchery) adults on the spawning areas, and documenting returns of $\mathrm{RBH}$ adults to WSNFH.

Increase competition and predation interactions with naturally-produced chinook, thus changing selection pressures. This could stimulate naturally-produced fish to progress toward extinction, or lose within-population genetic variability as the result of reduced effective population size. Eventual increases in production of wild chinook via habitat improvements could offset this.

Increase competition and predation interactions with mainstem trout and other native species, thus changing selection pressures. Potentially, this could cause affected native fishes to progress toward extinction, or lose within-population genetic variability via reduced effective population size.

Continue differentiation due to artificial selection and genetic drift between the hatchery and naturally-produced populations over time. This potential artificial selection effect can be controlled, to a degree, by exercising good husbandry practices in the hatchery (purposely admitting gene flow into the hatchery population from the natural population in the Deschutes River, avoiding breeding and rearing strategies that artificially select for specific characteristics, and being sure that the effective breeding population size in the hatchery is adequate).

Alternative 2. Release only a moderate number (for example, one-third) of the new production fish into the Deschutes River at Pelton; transport additional production to the Hood River Subbasin as a means of reestablishingruns of spring chinook of a more locally adapted stock.

\section{This action would:}

Present all of the potential genetic problems that may occur with Alternative 1, albeit at a much reduced degree of risk because only one-third the number of smolts would be released into the Deschutes River Subbasin, and fewer hatchery-produced adults will return.

Subject the fish living in the recipient subbasin to all these risks. For that reason, a thorough genetic risk analysis must be conducted in consideration of the native species of fish existing in the recipient subbasin. Such an assessment is currently being conducted for the Hood River Subbasin (Cramer 1991), which will describe in detail the potential effects of introducing Deschutes spring chinook smolts into the Hood River system.

A variation of Alternative 2 is to produce only one cell of "new production" spring chinook smolts in Pelton Ladder, and to rear part of the existing production of Deschutes summer steelhead smolts in the other two sections of expanded ladder. This action would have about the same in-system genetic effects as Alternative 2, except that it permits use of the expanded section of ladder while contingencies are being made to use the rearing potential for spring chinook in other profitable ways. However, based on the "quality" of spring chinook smolts reared in the ladder, the "quality" of summer steelhead that may be produced in the ladder may also be superior. This might reduce competition and predation effects by allowing release of a better summer steelhead smolt into the lower Deschutes River 
Based on smolt-release constraints stated in the Deschutes Subbasin Plan and the need expressed by the NEOH Fish Project team for good quality smolts for release in the Hood River Subbasin, implementation of Alternative 2 is recommended. 


\section{HARVEST GUIDELINES AND FISHERY BENEFITS}

Deschutes River spring chinook salmon are currently caught in ocean, Columbia River and Deschutes River mixed-stock fisheries. Existing harvest data indicate relatively few spring chinook originating above Bonneville Dam are harvested in offshore and Columbia River fisheries, although some are taken annually in the heavily-regulated sport, commercial, and tribal fisheries that remain in effect in the Columbia River. Most Deschutes River chinook harvest occurs in the Deschutes River Subbasin. Increased production of spring chinook in Pelton Ladder would, therefore, primarily benefit harvest in the stream where the smolts are released.

Harvest management of Deschutes River spring chinook in mixed-stock ocean and Columbia River fisheries will be governed by the Pacific Salmon Commission and Pacific Fisheries Management Council under the US-Canada Pacific Salmon Treaty. The states and tribes manage Columbia River harvests under the US v Qregon Columbia River Fish Management Plan (Columbia River Compact). Tagged (CWT) Deschutes River spring chinook caught in ocean and Columbia River fisheries will be sampled by existing programs and reported by the Northwest Mark Processing Center.

Co-management of spring chinook stocks within the Deschutes River Subbasin is a cooperative effort between ODFW and the CTWS. Harvest regulations for recreational fisheries in the subbasin are established by the Oregon Fish \& Wildlife Commission. The Warm Springs Tribe regulates all on-reservation fisheries, and also off-reservation fisheries by tribal members exercising their treaty rights.

Because of the currently depressed state of the upper Columbia River stocks of spring chinook salmon, of which the Deschutes River stocks are a part, harvest of upriver run spring chinook in ocean and mainstem Columbia River fisheries has been restricted or limited by the respective governing bodies.

The lower Columbia River catch of upriver fish varies with season timing, relative abundance and run timing. Under current guidelines, commercial fishermen in the lower Columbia River can harvest no more than 4.1 percent of the current pre-season prediction for upriver spring chinook return. Upriver spring chinook salmon reach peak abundance in the Columbia River in April and early May. Accordingly, the February and March winter season for tribal commercial harvest in the Columbia River happens prior to the peak run. In addition, mainstem tribal ceremonial and subsistence fisheries for spring chinook are managed according to inriver run size, expressed as the total number of adult spring chinook entering the Columbia River destined to pass above Bonneville Dam.

The lower Columbia River sport fishery harvests some upriver chinook in the legal season from March-May. However, this season may be closed in-season to avoid excessive catch of upriver spring chinook (Ring and McIsaac 1989). Although the catch of upriver spring chinook, including Deschutes River stock, is limited in ocean and mainstem river fisheries, increased production in the Deschutes River Subbasin in conjunction with enhancement efforts elsewhere may reverse this trend and allow for lifted restrictions and more harvest opportunity by both tribal and nontribal fisheries. However, management decisions to regulate or increase harvest of spring chinook in the ocean and Columbia River fisheries must consider and support subbasin efforts, such as the reestablishment and protection of natural stocks.

ODFW and CTWS management guidelines, and biological and utilization objectives for Deschutes River spring chinook are outlined in the Deschutes River Subbasin Plan. Harvest guidelines for spring chinook salmon in the Deschutes River Subbasin take into account run-size 
goals to the mouth of the Deschutes River, spawning escapement goals for natural stocks, hatchery broodstock collection goals, required mitigation levels, and evaluation requirements. Spring chinook salmon in the mainstem Deschutes River are managed for both natural and hatchery stocks. The Warm Springs River above WSNFH and Shitike Creek are managed exclusively for production of natural spring chinook stocks.

The Deschutes River Subbasin run size goal is for a annual return of 8,500 to 12,000 natural and hatchery spring chinook to the Deschutes River. The spawning escapement goal to the Warm Springs River and Shitike Creek combined is 1,400 to 2,500 natural spring chinook. Hatchery broodstock needs for WSNFH (at full capacity) and RBH (at the required mitigation level') are 1,000 and 1,200 adults, respectively (ODFW 1989). The monitoring and evaluation plan's hatchery effectiveness assessments will require observation and collection of CWT adults from returns to Pelton trap and in various fisheries. Provision of available surplus for recreational and tribal harvest purposes in the Deschutes River Subbasin is targeted for 5,500 to 8,000 spring chinook (ODFW 1989). All fish returning to Pelton trap above broodstock requirements will be provided to CTWS.

Currently, there are no specific harvest management goals or treaty and non-treaty harvest allocation agreements for spring chinook salmon in the lower Deschutes River Subbasin. However, additional harvest objectives outlined in the subbasin plan call for the provision of equitable harvest sharing opportunity in recreational and tribal fisheries along with an increase in harvest opportunities overall. At present, sport anglers catch about 70 percent of the total spring chinook harvest, and tribal fisheries harvest 30 percent. The current exploitation rate on hatchery and natural stocks is similar (31 percent and 29 percent, respectively), but this ratio may vary when more fish return. The large recreational and tribal fishery that occurs from Sherars Falls downstream to Buck Hollow Creek accounts for the majority of spring chinook harvest.

As run sizes increase with progressive attainment of run-size goals, fishing effort and harvest might increase. Although hatchery stocks can withstand higher harvest rates than natural stocks and still maintain production levels (due to higher survival from egg to smolt in the hatchery stock), restrictions on the harvest of natural spring chinook stocks may be needed in the future if returns of natural fish become reduced. This event has occurred twice previously (1981 and 1984) and resulted in the closure of recreational and tribal fisheries in the Deschutes River.

To increase harvest opportunity in the section below Sherars Falls, ODFW recently extended the legal area for fishing with bait for a distance of approximately two miles. Tribal fishermen have the right to fish at other suitable locations in the river. These locations may become more desirable when the chinook run size increases. 


\section{MONITORING AND EVALUATION PLAN}

\section{Introduction}

This section details the monitoring and evaluation plan to be applied towards increasing Pelton Ladder chinook production. This plan will evaluate the proposed changes in facilities and production methods to increase scientific knowledge of more effective ways to meet goals for return of spring chinook to the Columbia Basin and to the Deschutes River Subbasin.

When various attempts to increase or improve production are "monitored", the differences that occur as the result of the treatments are observed and measured. When these measured differences are "evaluated," they are analyzed to make effective comparisons. Good evaluation results in a previously unavailable level of scientific enlightenment that has general value and is an important component of the "Adaptive Management" process. A management and structure process currently exists in the subbasin that can quickly respond to new information that the study results may justify.

The monitoring and evaluation plan for this study was developed in a manner that is consistent with the Council's policies and procedures. Through a process of testing, analysis, and adaptive management, the study test results are expected to be data-based recommendations to fishery managers for culture and release of spring chinook into the Deschutes River Subbasin and other Columbia River subbasins. These recommendations will be designed to meet long-term goals for adult return, harvest and protection of natural fish and other watershed values. Results of these studies can be quickly and effectively implemented through the existing coordination process (see "Production Management and Structure Processes").

The goal of this project is to expand the capacity of Pelton Ladder to produce more chinook salmon smolts. This implies that project oversight will be provided, and there is a need to conduct corollary studies to ensure that the project is completed efficiently; the smolts reared are of good quality and provide the desired levels of adult return; and the project adequately addresses ecological and genetic elements of the river and hatchery environments. The monitoring and evaluation program was developed to determine if the project is meeting stated goals.

\section{Uncertainties and Potential Impacts}

The assigned responsibility of this study under Measure 703 (g) (3) of the Council's Fish and Wildlife program is a very production-oriented charge--to expand the production of anadromous salmonids in Pelton Ladder. A monitoring and evaluation program designed to address this measure is primarily an evaluation of the effectiveness of an existing, effective, low-capital, small-scale artificial propagation facility as affected by modifications needed to provide more space to produce more fish.

We have limited the scope of our detailed evaluations to assessing alternate methods of producing one species of anadromous fish. We anticipate that a modest increase in the number of smolts will be released into the Deschutes River Subbasin. However, recent interest has developed concerning transporting a portion of the ladder-reared smolts for release in the Hood River Subbasin. This prospective outplanting complexes the development of studies that rely primarily on Deschutes River Subbasin recoveries of tagged fish upon which to base hatchery effectiveness decisions.

This plan takes advantage of a draft subbasin plan that has weighed the relative value and risks of various methods of implementing several different measures to increase returns of adult salmon 
to the Deschutes River Subbasin. The subbasin plan identifies increased production of chinook salmon in Pelton Ladder as a preferred management alternative when conducted in concert with activities designed to correspondingly increase production of naturally spawned chinook in the subbasin.

There are many uncertainties associated with the proposed increase in Pelton Ladder smolt production. To assign priority to the importance of these uncertainties, they must be viewed in the context of historical perspective and evolution of fisheries management in the Deschutes River and Columbia Basin. Initial efforts were targeted at maintaining an existing, perhaps degraded, adult return number that remained after a major hydroelectric complex was constructed on the river. More recent management concerns are related to conducting propagation activities in concert with the need to maintain healthy populations of natural fish. Management decisions related to the fisheries of the Deschutes River are made by ODFW and CTWS. The subbasin planning process has detailed the preferred management strategies agreed to by the parties involved in management of the river.

There is not an opportunity to adequately study all uncertainties at Round Butte Hatchery (RBH), Pelton Ladder and the Deschutes River. However, since the primary charge of Measure 703 (g) (3) is to expand production, it is possible to:

- Evaluate changes in the RHB/Pelton Ladder production program, and make informed decisions whether the changes have been beneficial or detrimental. These evaluations provide inferences about the potential to further expand rearing in Pelton Ladder.

- Make observations regarding questions of larger concern to basinwide problems (residualism of released smolts, increases in catch rates of natural chinook, effects on populations of natural trout in the subbasin in response to the expanded rearing program), and contribute to scientific knowledge needed for effective adaptive management.

\section{Critical Uncertainties}

Critical uncertainties are concerns that transcend local (RHB/Pelton Ladder and Deschutes River) interests that could potentially affect the fisheries of the Columbia River:

\section{Will modifying Pelton Ladder to rear more fish reduce effectiveness of the existing production program at RHB/Pelton Ladder?}

Back ground: Through extended evaluation and increased production, the rearing program at RHB/Pelton Ladder now contributes substantially to the annual runs of "upriver" spring chinook salmon in the Columbia River. Inadvertent disruption of this program could have far-reaching effects, compromising the established program at the project, in the Deschutes River Subbasin, and the Columbia basin.

Proposed Evaluation: Monitoring activities will include measurements of smolt survival to permit comparisons of pre-modification vs post-modification adult production. Evaluation of these measurements will provide recommendations for continuation of the expanded production program, potential for further expanding production in Pelton Ladder, or reversion to the original rearing plan. These measurements will also be the basis for answering the question of how many adults could potentially result from further expansion of rearing capacity in Pelton Ladder. 


\section{What is the effective production potential of the cumently- unused sections of Pelton Ladder?}

If evaluation results indicate that spring chinook can be effectively reared in the newly-expanded section of Pelton Ladder, it can be inferred that this benefit may be extended to the space and flow limitations of the ladder. This opens the option of modifying Pelton Ladder to further expand rearing of anadromous fish, either for release into the Deschutes River Subbasin or for outplanting to other Columbia River tributaries. There are no plans to directly study the effects of rearing smolts in the upstream sections of Pelton Ladder. It was determined to be most logical to go to the expense of installing one additional rearing section in the ladder, and observing the effects on the existing, successful production program. If the existing program is not affected by this modification, we can imply that further expansion into other rearing sections is practical.

Proposed Evaluation: We will monitor and measure relative pre-modification and postmodification smolt survival rates. Results that indicate no significant differences in survival rate, or improved survival, will provide the bases for making the inference that we could further extend rearing in Pelton Ladder.

\section{Is there a consistent benefit associated with rearing fish in a semi natural environment?}

\&\&ground: Fish reared in Pelton Ladder have generally survived at higher rates than their counterparts reared entirely in formal hatchery ponds at $\mathrm{RBH}$, although in recent broods this difference appears to be narrowing (Figure 2). This apparent difference, together with results from similar experiences at other rearing facilities in the Columbia basin, generate a hypothesis that fish reared in semi-natural environs may generally have superior survival attributes. If so, fishery managers may be advised to seek out special opportunities to rear fish in lakes, ponds, or water bodies other than formal hatcheries. Better knowledge of this apparent phenomenon will contribute positively to basinwide experience in efforts to improve return of adults.

Proposed Evaluation: As part of the monitoring plan, we will measure differences in physical attributes of the rearing regimes (water temperatures, dissolved oxygen levels) in Pelton Ladder and at RBH. We will also cooperate with other BPA-funded studies designed to measure differences in "smolt quality" between $\mathrm{RBH}$ and ladder-reared smolts. We can also measure the amount of biological productivity in the water supply in the ladder above and below the rearing sections, and we can periodically examine the gut contents of smolts rearing in the ladder. We can correlate the results of comparisons of "smolt quality" measures with subsequent survival rates. However, the benefits of these observations will likely be additions to the inferential data thus available, rather than recommendations for changes in basinwide production modes. If a more detailed evaluation is warranted, we suggest initiating a separate project that deals specifically with compilation of the data related to semi-natural rearing facilities, identification of where in the Columbia basin these types of facilities currently exist or could be developed, and the indicated relative success of rearing in these environs.

\section{Will the proposed project jeopardize the genetic iutegrity of spring chinook in the Deschutes River?}

Background: See Genetic Risk Analysis section.

Proposed Evaluation: We will modify broodstock collection, spawning, and rearing practices insofar as practical (Rapuscinski 1991), recognizing that we do not have access to many naturally produced chinook as a source of genetic infusion. All chinook will be released as smolts to limit in-river competition potential. We will initially release about an additional 7,800 pounds of spring chinook into the Deschutes River at Pelton. Future increases in smolt releases at this 
upstream location will be contingent upon provision of substantial enhancements of natural production capabilities within the subbasin. We will continue to mark all smolts released to permit comparison of pre-project vs. post-project measurements of (1) straying of hatchery adults into natural production areas, (2) trend over time of RBH/Pelton Ladder adults arriving at WSNFH adult weir, and (3) trend of rate of natural Deschutes chinook harvest in sport and commercial fisheries.

\section{Secondary Uncertainties}

Secondary uncertainties, while perhaps critical to the successful conduct of the proposed evaluation, have a narrower scope that is generally limited to the Deschutes River Subbasin and the $\mathrm{RBH} /$ Pelton Ladder rearing program.

\section{Will the proposed project affect resident trout in the Deschutes River?}

Release of substantially greater numbers of hatchery-reared spring chinook smolts presents the potential for competition with natural trout populations. However, data collected over several years indicate a large and healthy trout population in index areas of the river, and current trout harvest regulations on the lower Deschutes River are extremely restrictive.

Proposed Evaluation: Because of the low statistical sensitivity of field sampling trout populations in large streams such as the Deschutes River, we will rely on prudently limiting smolt releases rather than initiating trout population sampling in standard index areas of the river. Although substantial trout population data exists, the data show variations over time, changes that cannot be specifically traced to causative effects. It is our judgement that it is likely unproductive to try to use trout population data to try to define effects of the Pelton project. We propose to limit the numbers of smolts released, and to outplant most of the smolts produced in Pelton Ladder.

\section{Can effective production goals for spring chinook smolts reared in RBH, the existing (old) section of Pelton Ladder, and the proposed (new) section of Pelton Ladder be defined?}

Background: Previous studies have defined a production program that works well enough to meet mitigation requirements (Lindsay and Jonasson 1989). These evaluations have illustrated the benefits of releasing slow-incubated smolts averaging 6-12/pound in April. Managers believe needed refinements of this program include identification, through replicated tests, of most effective smolt size goals for the hatchery-produced smolts and the ladder-produced smolts (the goals may be independent). It would be advantageous to define effects of density in the rearing units, but pond-space limitations preclude making simultaneous comparisons of multiple hatchery-effectiveness parameters. Instead of evaluating effects of rearing density, we will intentionally stock all rearing units at low densities in order to negate density effects on results (7,700 pounds of smolts per cell terminal stocking density in each cell of the ladder, and 2,500 pounds per pond in $\mathrm{RBH}$ rearing ponds).

Proposed Evaluations:

A. Conduct livebox tests in Pelton Ladder to define time of safe transfer from RBH to the rearing cells in the ladder. By controlled tests, determine the effects of early (September) transport to the ladder for rearing. 
B. Using standard terminal stocking densities (pounds of smolts/unit of rearing water at time of release) and standard (early April) release times, compare survival of:

1) Medium vs. small smolts (ladder-reared)

2) Medium vs. small smolts (RBH-reared)

3) Rearing in "new" ladder section vs. rearing in "old" ladder section

4) Smolts reared in the modified "old" ladder section in relation to survival rates established for this ladder section by previous studies.

\section{Prioritization of Uncertainties}

Much of what we propose in the monitoring and evaluation studies deals with refining hatchery effectiveness criteria in Pelton Ladder and at RBH. Successful accomplishment of these studies is less important to achievement of basinwide goals for return of adults than, for example, determining if modifying the ladder has reduced the overall ability of the ladder to effectively produce smolts that will survive to return as adults.

The rationale for establishing priority of uncertainties appears in Table 4. 
Table 4. Criteria for establishing priority of uncertainties.

\begin{tabular}{|c|c|c|c|c|c|c|}
\hline \multirow{2}{*}{\multicolumn{2}{|c|}{ Uncertaintv }} & \multirow{3}{*}{$\begin{array}{l}\text { Expected } \\
\text { evaluation }\end{array}$} & \multirow{3}{*}{$\begin{array}{l}\text { Basinwide } \\
\text { application }\end{array}$} & \multicolumn{3}{|c|}{ Critical knowledae importance to: } \\
\hline & & & & \multirow{2}{*}{$\begin{array}{l}\text { Systemwide } \\
\text { application }\end{array}$} & \multirow{2}{*}{$\begin{array}{l}\text { Deschutes } \\
\text { subbasin }\end{array}$} & \multirow{2}{*}{$\begin{array}{l}\text { RBH/Pelton } \\
\text { Program }\end{array}$} \\
\hline Type & No. & & & & & \\
\hline Critical & 1 & $\begin{array}{l}\text { Compare pre-post } \\
\text { mod. adult } \\
\text { production }\end{array}$ & Yes & Yes & Yes & Yes \\
\hline Critical & 2 & $\begin{array}{l}\text { Production potential } \\
\text { of unused ladder }\end{array}$ & Yes & Yes & Yes & Yes \\
\hline Critical & 3 & $\begin{array}{l}\text { Benefits of semi- } \\
\text { natural production }\end{array}$ & Yes & Yes & Moderate & Yes \\
\hline Critical & 4 & $\begin{array}{l}\text { "Genetic integrity" } \\
\text { compromises }\end{array}$ & Yes & Moderate & Yes & Yes \\
\hline Secondary & 5 & $\begin{array}{l}\text { Effect on resident } \\
\text { species in river }\end{array}$ & Moderate & Moderate & Yes & Yes \\
\hline Secondary & 6 & $\begin{array}{l}\text { Effective production } \\
\text { program for } \\
\text { RBH/Pelton Ladder }\end{array}$ & Moderate & Moderate & Yes & Yes \\
\hline
\end{tabular}




\section{Experimental Approach}

\section{Critical Uncertainty 1: Will modifying Pelton Ladder reduce effectiveness of the existing production program?}

Objective 1: Measure survival of smolts produced in the (new) modified sections of Pelton Ladder and compare to (old) established pre-modification survival rates.

Hypothesis 1.1: Survival to adults of smolts produced in the new section of Pelton Ladder will be no different than survival of smolts produced in the old section of Pelton Ladder.

Planned Evaluation: We are limited in the number of replicate groups we can release. However, we will maintain at least one cell of "new production" smolts as a direct comparison of relative survival rates with one cell of "old production" smolts to answer this question. (cells L-l and L-4, Table 5 and Figure 4, illustrate this comparison).

CheckpointsIamidial results of the proposed evaluation will be available at the point when two consecutive broodyears of tagged adults have returned as age-4 adults. Final results will be available at study completion. Results will dictate recommendations for continuation of the expanded production program, potential for further expansion production, or discontinuation of the expanded rearing and reversion to the original rearing program.

Hypothesis 1.2: Survival rates of smolts produced in the old section of Pelton Ladder (as modified) will not differ significantly from survival rates of smolts produced in this section of ladder prior to ladder modification, as has been demonstrated by past studies (mean $=1.6$ percent).

Planned Evaluation: We have retained one cell of "old production" smolts (cell L-l, Table 5 and Figure 4) as a means of comparison to this established, long-term standard, which we continue to monitor as part of "pre-project" conditions.

Checkooints_and_Recommendations: Initial results of the proposed evaluation will be available at the point when two consecutive broodyears of tagged adults have returned as age- 4 adults. Final results will be available at study completion. Recommendations will be predicated upon whether the new production program has interfered with the efficiency of the existing, proven effective rearing program. We will make suggestions for modifying, continuing, or discontinuing the new rearing program. The TWG sets a high priority on maintaining the efficiency of the existing spring chinook production program at $\mathrm{RBH} / \mathrm{Pelton}$ Ladder. 
Table 5. Proposed hatchery effectiveness test, RBH and Pelton ladder, based on the scenario:

- No wild fish enhancement implemented in the watershed

- Decision made to outplant ladder smolts to NE Oregon basins

$\begin{array}{llllll}\text { Pond Smolts Tags F/lb Lbs. Funding } & \begin{array}{l}\text { Ship to } \\ \text { ladder }\end{array} & \begin{array}{l}\text { For } \\ \text { release }\end{array}\end{array}$

\begin{tabular}{|c|c|c|c|c|c|c|c|}
\hline H-I & 20,000 & $20 \mathrm{~K}$ & 8.0 & 2,500 & \multicolumn{2}{|l|}{ PGE } & Deschutes River \\
\hline $\mathrm{H}-2$ & 30,000 & $30 \mathrm{~K}$ & 12.0 & 2,500 & \multicolumn{2}{|l|}{ PGE } & Deschutes River \\
\hline L-I & 62,216 & $30 \mathrm{~K}$ & 8.0 & 7,777 & PGE & Nov. & Deschutes River \\
\hline L-2 & 62,216 & $30 \mathrm{~K}$ & 8.0 & 7,777 & PGE & Sept. & Deschutes River \\
\hline L-3 & 93,324 & $30 \mathrm{~K}$ & 12.0 & 7,777 & PGE & Nov. & Deschutes River \\
\hline L-4 & 62,216 & $30 \mathrm{~K}$ & 8.0 & 7,777 & BPA & Nov. & Deschutes River \\
\hline L-5 & 62,216 & $30 \mathrm{~K}$ & 8.0 & 7,777 & BPA & Sept. & $\mathrm{NEOH}$ outplants \\
\hline L-6 & 62,216 & $30 \mathrm{~K}$ & 8.0 & 7,777 & BPA & Sept. & $\mathrm{NEOH}$ outplants \\
\hline TOT & 54,404 & $230 \mathrm{~K}$ & & 51,662 & & & \\
\hline
\end{tabular}

Variable Tested

Effective smolt size

Effects time of transfer to ladder

Effects of ladder modification

\section{Compare Survivals}

$\mathrm{H}-\mathrm{I}=\mathrm{H}-2$ (hatchery)

L-I = L-3 (ladder)

$\mathrm{L}-\mathrm{I}=\mathrm{L}-2$

$\mathrm{L}-\mathrm{I}=\mathrm{L}-4$

$L-4=1.6 \%$ 


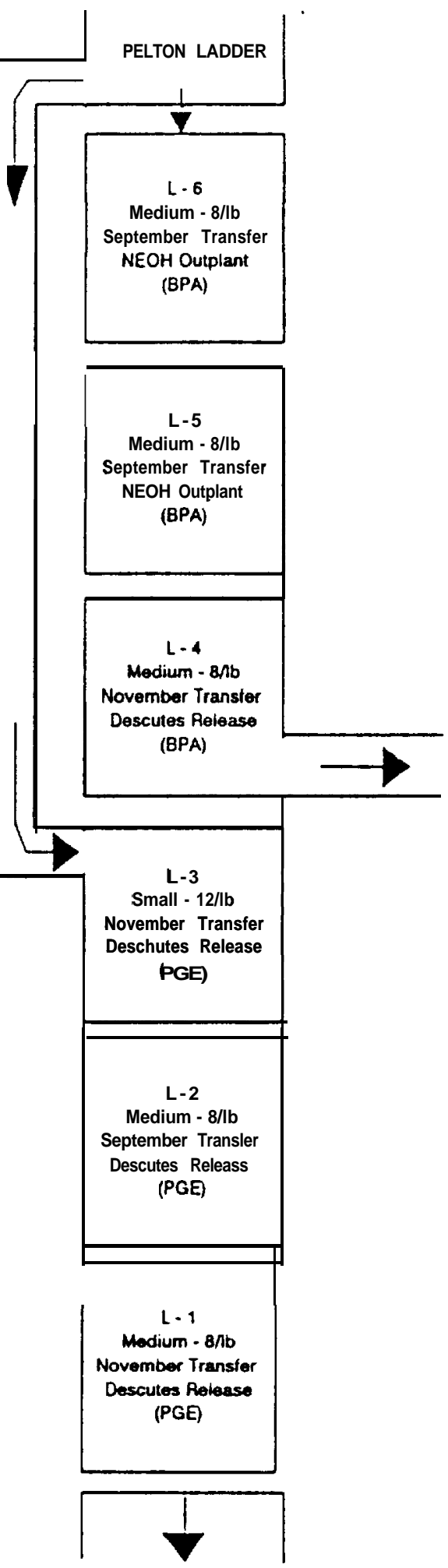

Fi gure 4. Recomended pondi ng pl an for RBH Pel ton Ladder to acconodate producti on of study $\mathrm{fi}$ sh. 
critical Uncertainty 2: What is the effective pmduction potential of the currently, unused area in Pelton Ladder?

Objective: Measure adult return provided by the new modification to Pelton Ladder to gain inferences about the potential value of further extending production in the ladder.

Hypothesis 2.1: (Same evaluation as Hypothesis 1.1).

Planned Evaluation: If smolts in cell L-4 (Table 5 and Figure 4) survive at rates equal or greater than smolts from cell L-I, and if mean survival rates of smolts from cell L-l approximate the long-term standard (1.6 percent), we can infer that provision of the new section of rearing has not adversely affected the existing production program, and it may be practical to develop more rearing cells in Pelton Ladder.

Checkooints and Recommendations: We need at least two years of age- 4 adult return to begin comparison of survival rates between cell L-4 and L-l, but we really need to complete the study to get meaningful average survival percentage comparisons. From these data, we can recommend whether it is practical to consider building additional ladder rearing sections.

Critical Uncertainty 3: Is there a consistent benefit in rearing fish in a semi-natural envimnment?

Objective: Review measures of relative "smolt quality" between fish reared in Pelton Ladder and $\mathrm{RBH}$ as inferences that ladder-reared smolts may have superior "fitness" for survival.

Hypothesis 3.1. Physiological indicators of "smolt fitness" will not differ between ladder-reared and RBH-reared chinook smolts.

Planned Evaluation: Physiologists funded by BPA have sampled several broods of ladderreared and RBH-reared smolts. These data will be compiled and analyzed to provide a comparison of relative physiological "fitness" between the groups of fish. ,We will also provide observational data related to relative availability of natural foods in $\mathrm{RBH}$ and Pelton Ladder water supplies, and the incidence of these natural foods in the guts of rearing smolts.

Checkpoints and Recommendations: Physiological comparisons should be available in early 1992. Analyses of water organics and stomach contents will be available during the first year of rearing. Recommendations will be general in nature, and may include an amendment to the Council's Fish and Wildlife Plan for a more detailed study to be conducted at several seminatural rearing facilities throughout the Columbia River Basin.

Hypothesis 3.2: Survival rates of smolts produced in Pelton Ladder will not differ significantly from survival rates of smolts produced in $\mathrm{RBH}$.

Planned Evaluation: Comparison of survival rates experienced by similar-size smolts released at the same time (Pond H-l vs cell L-l and Pond H-2 vs cell L-3, Table 5 and Figure 4) will provide this analysis.

Checkpoints and Recommendations: Initial results of the proposed evaluation will be available at the point two consecutive brood years of tagged adults have returned as age-4 fish. Final results will be available at study completion. Recommendations made will be based on integrated results of this evaluation and results of hypotheses 1.1, 1.2, and 2.1, which relate to how the modification of the ladder has affected the efficiency of the existing rearing program. Suggestions may be to maintain, increase, modify, or discontinue the new rearing program. 


\section{CriticaI Uncertainty 4: Will releasing more hatchery-reared spring chinook from RBH/Pelton ladder jeopardize the genetic integrity of Deschutes spring chinook?}

Objective: Derive inferences of adverse interactions between hatchery and natural spring chinook in the Deschutes River.

Hypothesis 4.1: Numbers and rates of adults straying into natural production areas in the Deschutes River will not be significantly different post-project compared to pre-project.

Planned Evaluation: All hatchery spring chinook smolts (RBH, Pelton Ladder, or WSNFH) released into the Deschutes River will continue to be externally marked during these tests as an extension of a long-standing management policy. Project personnel will annually sample carcasses of adult spawners in Shitike Creek, the lower Warm Springs River, and lower White River to establish a baseline proportion of wild/hatchery mix. Project personnel will also tabulate the past data available. Records of wild/hatchery ratios returning to WSNFH past, current, and in the future will be tabulated and analyzed. Maintenance of these data will detect trends in the proportion of hatchery fish changes over time in response to increased production releases from Pelton Ladder.

Checkpoints and Recommendations: Baseline data are currently being collected as manpower constraints permit. Project personnel will expand these surveys to be more inclusive of all appropriate locations during the period before project-produced adults return as points of reference for comparison. When project-produced adults return, increases in the ratios of hatchery-produced adults returning to mix on spawning areas and to WSNFH could lead to recommendations to curtail or modify the expanded rearing program.

Hypothesis 4.2: Catches of natural Deschutes River spring chinook (exploitation rates and total numbers) in Columbia River and Deschutes River fisheries will not be significantly different post-project compared to pre-project.

Planned Evaluation: A substantial long-term data set exists related to hatchery/wild proportions of adult spring chinook in the Sherar's falls fisheries. Project personnel will continue to monitor this proportion over time and determine if changes occur in response to increased smolt releases from the expanded production in Pelton Ladder.

Checkoomts and Recommendations: These results will support and complement evaluations proposed in Hypothesis 4.1. Recommendations will be made on the same time schedule.

\section{Secondary Uncertainty 5: Will the project jeopardize resident trout populations?}

Objective: Compare trout populations pre-project and post-project to detect possible indications of adverse effects.

Hypothesis 5.1: Resident trout populations in select index areas will not be significantly different post-project compared to pre-project.

Planned Evaluation: Limited statistical sensitivity involved in measuring differences in fish populations in large rivers reduces the ability to satisfactorily make these comparisons. We choose to prudently limit the numbers of additional smolts released, rather than attempt this likely-unproductive assessment. 


\section{Secondary Uncertainty 6: Can effective production goals for spring chinook smolts reared in RBH and the sections of Pelton Ladder be defined?}

Objective: Conduct controlled tests to define effective smolt production criteria that maximizes adult return.

Hypothesis 6.1: There will be no significant differences in smolt-to-adult survival rates between groups transferred to Pelton Ladder in September compared to November.

Planned Evaluation: By transferring part of the production from the starting ponds in $\mathrm{RBH}$ in September, we negate the need to incorporate expensive additional starting ponds at $\mathrm{RBH}$ into the cost of the project. September transfer to Pelton Ladder of fingerlings started at RBH is not a part of the normal production program, and needs to be evaluated. Comparison of relative survival rates experienced by rearing cell L-l compared to cell L-2 ( Table 5 and Figure 4) will provide this analysis.

Checkpoints and Recommendations: $\mathrm{RBH}$ personnel will derive initial information related to this evaluation by subjecting 1990-brood smolts to liveboxes in Pelton Ladder in September, 1991 (thus simulating early transfer to the ladder), If these smolts survive satisfactorily and show no unusual pathology, the recommendation will be to continue with preparation for ladder modification. Initial results of evaluation of Hypothesis 6.1 will be available at the point two consecutive brood years of tagged adults have returned as age- 4 fish. Final results will be available at study completion. If September transfer to Pelton Ladder works as efficiently as November transfer, and growth of smolts in the ladder can be controlled, September transfer offers an option for flexibility of the rearing program at $\mathrm{RBH}$.

Hypothesis 6.2: Mean size at release of ladder-reared smolts will not significantly affect smoltto-adult survival rates,

Planned Evaluation: Previous data collected at RBH/Pelton Ladder indicates smaller smolts (12/lb at release) may survive as well or superior to larger smolts (8/lb at release). However, these comparisons were available only between rearing years. We have incorporated withinyear comparisons in our hatchery effectiveness tests. ( Cell L-l compared to cell L-3 in Pelton Ladder, Figure 5).

Checkooints and Recommendations: Initial results of the proposed evaluation will be available at the point two consecutive brood years of adults have returned as age- 4 adults. Final results will be available at project completion. Recommendations will include suggestions for target sizes of smolts released from Pelton Ladder.

Hypothesis 6.3: Mean size at release of hatchery-reared smolts will not significantly affect smoltto-adult survival rates.

Planned Evaluation: Similar test as above (Hypotheses 6.2), but for RBH-reared smolts. Comparison of survival rates from smolts reared in hatchery pond H-l vs H-2 ( Table 5 and Figure 4) will permit this analysis.

Checkpoints and Recommendations: Initial results of the proposed evaluation will be available at the point two consecutive brood years of adults have returned as age- 4 adults. Final results will be available at project completion. Recommendations will include suggestions for target size of smolts released from RBH ponds. 
Study results and recommendations can be transmitted to managers at the annual RBH program review, at the twice-yearly Fish Management/Fish Propagation meeting, or directly from project personnel to the district fishery biologist and RBH Manager in coordination with ODFW's Central Regional Office.

\section{Hatchery Effectiveness Experiments}

Experimental opportunity for conducting hatchery effectiveness tests is limited by hatchery capacity at RBH. Experiments have been designed around the constraints voiced by the TWG: keep the production program at $\mathrm{RBH}$ as unchanged from the existing program (which is finally meeting mitigation requirements) as possible, and do not include addition of more starting ponds at $\mathrm{RBH}$ which would substantially affect the "low cost" nature of the proposed project.

In defining relative importance of experimental uncertainties, we defined critical uncertainties as those issues that extend beyond the scope of Deschutes River Subbasin interests. Detailed evaluations related to these critical uncertainties are not provided as they are beyond the scope of the enabling Measure. We plan to conduct many hatchery effectiveness studies, which we define as secondary uncertainties that are of direct concern to the Deschutes River Subbasin and its artificial production programs. Critical uncertainties affect more global concerns; secondary uncertainties are more local to the Deschutes River and the RBH production program.

Ideally, each treatment and control group of tagged fish released should be replicated twice each year, and again replicated for multiple years. Limited by facilities, we can rarely replicate within a brood year. Where opportunity for replication exists, we have chosen to repeat within a year, those groups which most closely represent current production criteria as a means of maintaining continuity of the existing production program and, presumably, adult return to the lower Deschutes River.

Facility limitations, lack of sufficient starting ponds and limited number of additional rearing cells in Pelton Ladder, dictate that we will not be able to address questions that may be valuable sources of operational information, such as:

- Effects of stocking density on survival of comparable-size smolts, in both the hatchery and the ladder.

- Differences in potential rearing capacity in the sections of Pelton Ladder with steeper gradient.

- Refinements in knowledge regarding how time-of-release affects smolt survival.

- Direct measures of the ultimate production potential of Pelton Ladder.

- Effects that specific rearing cells may have on survival rates of ladder-reared smolts.

Sensitivity analyses indicate releasing groups of 20,000 tagged fish per test or control group, for four consecutive brood years, has a high probability of detecting differences of 30 to 50 percent in survival rates between groups (Figure 5). Plans are to release groups containing 30,000 CWT smolts, and these releases will be repeated over four consecutive broods. Adult returns will begin two years after the first smolts are released and will be completed two years after the last smolts are released. 


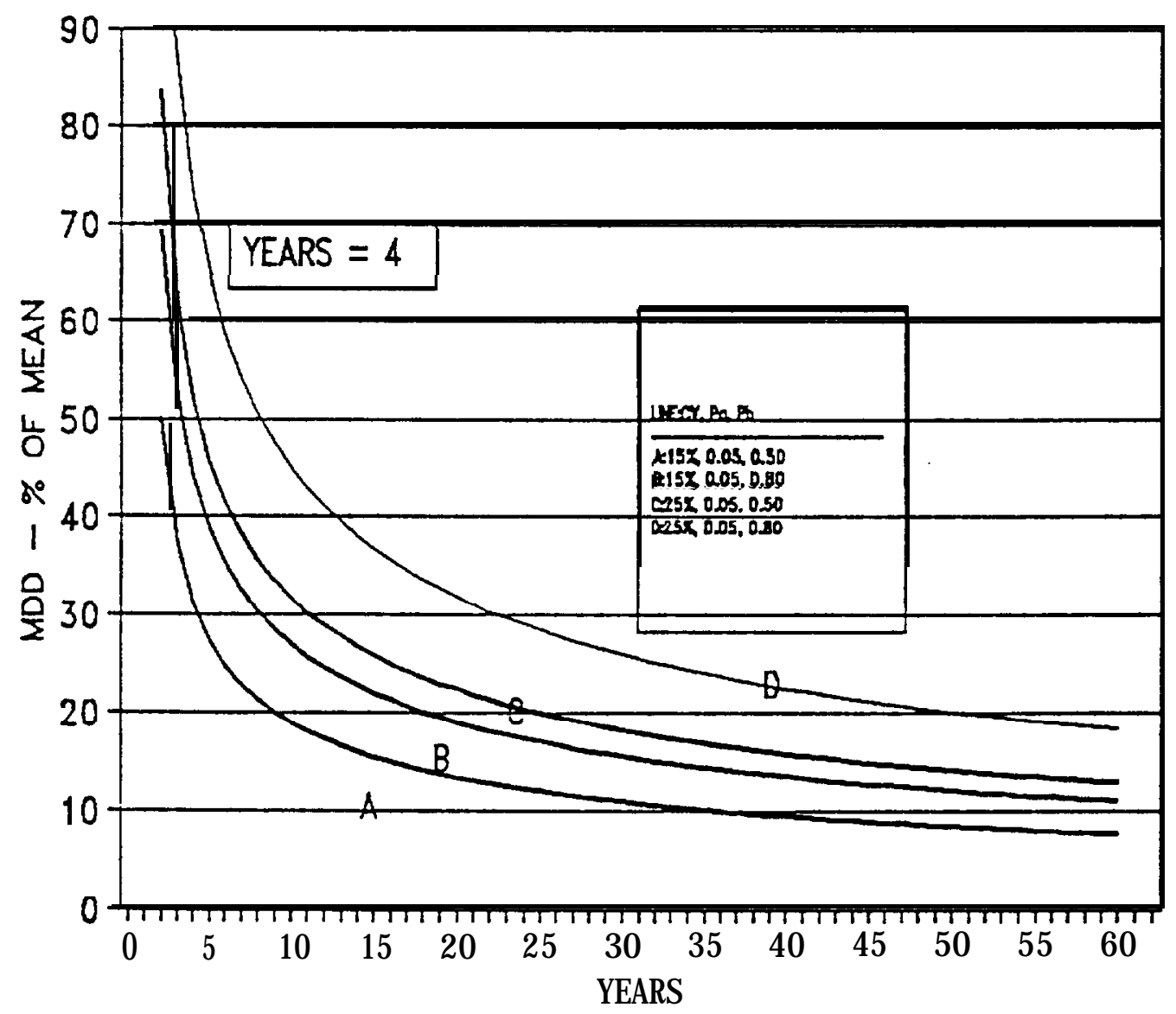

Figure 5. Sensitivity curves determined for statistical analyses of smolts release evaluations, RBH/Pelton ladder (Mary Buckman, ODFW Biostatistician, February 1990). Past results indicate the $15 \%$ CV curves may apply best. 
Hatchery effectiveness assessments, derived by comparing adult returns between test and control groups of released smolts, will be conducted over four consecutive brood years. This should result in the ability to distinguish 30 to 50 percent differences in mean survival rates with 95 percent certainty.

All smolts released will be given an external mark which identifies them as of hatchery origin. The external mark applied to RBH/Pelton Ladder smolts will be different than the external mark applied to WSNFH smolts as a means of maintaining distinct records of brood year success, by hatchery of origin, in Deschutes River fisheries.

Tags will be collected from Ad+CWT adults sampled in Deschutes River sport and tribal fisheries, and from adults collected at Pelton Ladder and WSNFH. Estimates of harvest of project-generated fish in offshore and Columbia River fisheries will be gathered from standard reports supplied by the Northwest Mark Processing Center.

Personnel supported by this project will annually survey carcasses in natural production areas (Lower Warm Springs River, Shitike Creek) and lower White River (which is not historically a natural production area for spring chinook salmon) to document potential intrusion of hatcheryproduced fish, and changes over time.

Samplers at Sherars Falls will annually document the relative proportion of natural and hatchery fish in the catch, thus providing the basis for decisions whether this ratio changes significantly over time.

\section{Recommendations for Fish Releases and Release Sites}

It is believed that the intent of the Deschutes Subbasin Plan's preferred alternative for spring chinook production conditions major increases in releases of hatchery-produced fish upon corresponding increases in natural fish production. Based on this management constraint, we recommend restricting additional numbers of ladder-reared smolts to be released into the Deschutes River.

We recommend modifying Pelton Ladder to achieve the capability of rearing an additional 25,000 pounds of spring chinook smolts, which approximately duplicates the existing rearing capability of the ladder (Table 5). We expect to rear full capacity volumes of fish in these new rearing cells. However, we recommend limiting the release of these new-production smolts into the Deschutes River be limited to the capacity of only one of the new cells (62,200 smolts). The additional 124,000 smolts should be removed from the ladder and, as recommended by the NEOH Fish Project, transported to the Hood River Subbasin for release.

The proposed production scenario needed to achieve these rearing and release strategies, along with proposed tests of hatchery effectiveness that will be pursued, are displayed in Figure 4 and Table 5. (Minor adjustments in cell arrangements may be made at the discretion of the hatchery manager to facilitate efficient rearing and release.) 


\section{Monitoring Sites}

The sampling of juveniles during the rearing phase will occur in the $\mathrm{RBH}$ rearing ponds and in Pelton Ladder.

Adults caught in offshore fisheries will be sampled via established protocols, and numbers in actual and expanded catches will be reported by the Northwest Mark Processing Center. Columbia River harvest of tagged Deschutes River chinook will be sampled and reported by ODFWs Harvest Management section.

Adult chinook which enter the Deschutes River are sampled in the sport and tribal fisheries at Sherars Falls, and many return to the trap at Pelton Ladder. We will investigate reports of a substantial fishery for spring chinook that is developing in the lower Deschutes river below the existing "bait allowed" area. Some adults enter the Warm Springs River, but a weir at WSNFH permits trapping, counting, and prevention of hatchery-produced adults from moving above the weir into the upper Warm Springs River.

An adult trap on the fishway at Sherars Falls can be operated to capture samples of natural and hatchery-reared adults that migrate above this natural obstacle. However, we do not anticipate the need to operate this trap to collect tagged adults; we will collect sufficient tags by sampling fisheries and hatchery returns to make the needed statistical analyses.

Natural spawning areas other than the Warm Springs River include Shitike Creek, and adult spring chinook may stray into and spawn in lower White River. Observations of adult entry and spawning in these streams may be a useful index of the revised hatchery program effects.

Currently, no facilities exist to trap adults which enter White River. However, potential development of a program to provide passage at White River Falls will incorporate an adult trapand-transport system as part of the necessary facilities. Should this facility become available, we would monitor adults at this location.

Observations of trout populations pre-project and post-project is an option for initiation in selected index areas of the mainstem Deschutes River and in the Deschutes River below the reregulating dam for Pelton Reservoir.

The North East Oregon Fish Project planning effort prescribes that some Pelton Ladder smolts be outplanted to the Hood River. If this approach is implemented, facilities for smolt acclimation, adult monitoring, broodstock collection and broodstock isolation would likely be needed. A draft monitoring plan for Hood River supplementation is being developed (Hood River Production Plan 1991). Facilities described in the Hood River Monitoring and Evaluation Plan will be used to collect data related to the Pelton Ladder monitoring and evaluation plan as well as collecting data needed by the NEOH TWG. 


\section{MANAGEMENT POLICIES AND GUIDELINES}

This study will be conducted in accordance with all applicable federal, state, and tribal laws, and will be governed by the existing management and structure processes currently in place for the operation of the RBH/Pelton Ladder production complex. This process includes annual review of operations by ODFW, CTWS, USFWS, and PGE personnel. Council and BPA personnel will be included in this review team during the term of the study.

Expansion of production of salmon smolts in Pelton Ladder is consistent with the Council's stated need to increase the returns of anadromous fish to the Columbia River, and satisfies Measure 703 (g) (3) of the Columbia River Fish and Wildlife Plan.

The increased return of spring chinook that will result from this project is consistent with the needs and preferred management alternatives stated in the Deschutes River Subbasin Plan. We practiced restraint in scheduling additional releases of hatchery-reared spring chinook into the Deschutes River. We have provided outplanting options for making profitable use of the majority of the additional production of hatchery-reared smolts that will be provided by this project.

This program has been developed as a joint effort of ODFW, CTWS, the Council, BPA, and PGE. CTWS has been involved in the decisions and strategies contained in this master plan, and is an active participant in the studies to be conducted. We have taken care to insure the project is

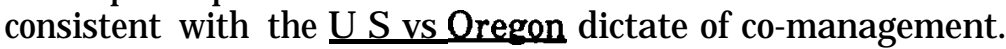

We specify that conduct of the project will not affect PGE's existing mitigation responsibility, and project funds will defray any additional expenses incurred to operate the needed rearing, marking, and study processes. PGE has agreed to permit needed modification to their facilities, and will provide the necessary increased flow in Pelton Ladder needed to rear the additional smolts.

Fish culture practices employed in the study will be consistent with ODFW policies for all phases of hatchery operation, including broodstock collection, disease control, fish rearing, transport and release. Releases of reared fish, whether in the Deschutes River Subbasin or at remote outplanting sites, will be controlled by appropriate administrative and pathology review and approval.

Implementation of the facility modification, production of fish, study processes, supplementation activities and harvest protocols will all be subject to review and approval by appropriate Council, CBFWA, State and Tribal representatives. 


\section{IMPLEMENTATION SCHEDULE}

It is expected that review of this master plan will be completed by mid-1991. If this Phase I document and production concept is approved for further implementation, a period of engineering design and cost estimate refinement will follow. Review of design and refinement of cost estimates should be completed during 1991. If deemed economical and practical, the Phase II facility modifications will be completed in time to permit the new section of Pelton Ladder to receive 1992-brood spring chinook smolts in September 1993. Because of the need to rear 1990-brood smolts in Pelton Ladder from November 1991 until April 1992, modification to the ladder will necessarily be restricted to the period from April to late August 1992.

Rearing and release of fish for this study will consist of four consecutive brood years (1992-1995). Age-3 jacks of the first brood will return in 1995, and the last expected return of project fish will occur as age- 5 adults from the 1995 brood in 2000 . However, since age-5 adults make up only about 2 percent of the return of spring chinook to $\mathrm{RBH}$, the last meaningful adult return will occur in spring and summer 1999.

Preparations for the first full-scale rearing operations will begin with broodstock collections in May 1992. Egg take will occur in August and September 1992, and the eggs will be slow-incubated in the expanded chilling facilities at RBH until time of ponding in February or March of 1993. Fry will be reared in the ponds at $\mathrm{RBH}$ until July, at which time the fish will be marked, tagged, and ponded in accord with the plan expressed in Table 5. About 187,000 smolts will be transferred to Pelton Ladder in September 1993, to be followed in November by the remaining complement of about 218,000 smolts destined for ladder rearing. An additional 50,000 smolts will be retained at $\mathrm{RBH}$ in the formal rearing ponds for finish rearing. All 454,000 smolts of the 1992 brood will be released in April 1994. However, only 330,000 will be released into the Deschutes River at Pelton; the remaining 124,000 will be outplanted to locations identified by the Northeast Oregon Fish Project team, but presumably to the Hood River.

All subsequent broods (1993-1995) of study fish will follow this general pattern of fish culture and release. Field studies designed to monitor harvest and spawning of hatchery produced fish will begin in May 1992 as an extension of measures of pre-project effects. Rate of intrusion of hatchery salmon into accessible natural spawning areas will begin in September 1992. Both these field activities will continue seasonally throughout the duration of the study.

Table 6 illustrates the expected schedule of study activities from inception in 1992 through 1999. 
Table 6. Schedule for conduct of basic activities, Pelton Ladder rearing study.

\begin{tabular}{|c|c|c|c|c|c|c|c|c|c|}
\hline Activity & $\begin{array}{l}\text { Prime } \\
\text { activity } \\
\text { months }\end{array}$ & 1992 & 1993 & 1994 & 1995 & 1996 & 1997 & 1998 & 1999 \\
\hline Design, engineering, modify ladder & $10-4$ & & - & & & & & & \\
\hline Collect adults for brood & $5-9$ & $\mathbf{x}$ & $\mathrm{x}$ & $\mathrm{x}$ & $\mathrm{x}$ & & & & \\
\hline Husband juveniles/eggs & $\begin{array}{l}1992 \text { brood } \\
1993 \text { brood } \\
1994 \text { brood } \\
1995 \text { brood }\end{array}$ & 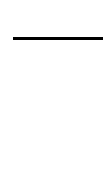 & & - & & & & & \\
\hline Mark test smolts & 10 & $\mathrm{x}$ & $\mathbf{X}$ & $\mathrm{x}$ & $\mathrm{X}$ & $\mathrm{x}$ & & & \\
\hline Pre-release sarnpling & $3-4$ & $\mathrm{x}$ & $\mathrm{x}$ & $\mathbf{X}$ & $\mathbf{x}$ & $\mathrm{x}$ & $\mathrm{x}$ & & \\
\hline Collect tags from returnlng adults & $5-9$ & a & a & a & b & b & b & b & b \\
\hline Sample Deschutes fisheries & $5-7$ & $\mathbf{x}$ & $\mathbf{x}$ & $\mathbf{x}$ & $\mathbf{x}$ & $\mathbf{x}$ & $\mathbf{x}$ & $\mathbf{x}$ & $\mathbf{x}$ \\
\hline Spawning surveys (straying) & $8-10$ & $\mathbf{x}$ & $\mathbf{x}$ & $\mathbf{x}$ & $\mathbf{x}$ & $\mathbf{x}$ & $\mathbf{x}$ & $\mathbf{x}$ & $\mathbf{x}$ \\
\hline Oral results, annual report & 5 & $\mathrm{x}$ & $\mathrm{x}$ & $\mathrm{x}$ & $\mathrm{x}$ & $\mathrm{x}$ & $\mathrm{x}$ & $\mathbf{x}$ & $\mathrm{x}$ \\
\hline Dat'a summaries and analysis & Year round & $\mathbf{x}$ & $\mathrm{x}$ & $\mathrm{x}$ & $x$ & $\mathrm{x}$ & $\mathrm{x}$ & $\mathbf{x}$ & $\mathrm{X}$ \\
\hline Final report & 12 & & & & & & & & $\mathbf{X}$ \\
\hline Coordination - ODFW/CTWS/BPA & Year round & $\mathrm{X}$ & $\mathbf{x}$ & $x$ & $x$ & $\mathbf{x}$ & $x$ & $\mathrm{x}$ & $\mathbf{X}$ \\
\hline NPPC/MEG/GEM/PGE & & & & & & & & & \\
\hline
\end{tabular}

a Collect tags from adults returning from previously marked broods as continuation of baseline data.

$b$ Collect fags from adults returning from Pelton Ladder smolt releases. 


\section{COSTS AND FUNDING}

\section{Services and Supplies, Operations and Maintenance}

PGE will continue to fund the major portion of the spring chinook production at RBH/Pelton Ladder. We propose to produce about 51,662 pounds of spring chinook smolts per brood, and PGE will fund the production of 28,331 pounds. The project will fund production of the difference, or about 23,331 pounds of spring chinook smolts per brood. Of the project costs for fish production, 7,777 pounds are expected to be charged to the Pelton study, and 15,554 pounds will likely be supported by the Northeast Oregon Project, since these fish will be outplanted.

The production of additional fish will increase the normal operations and maintenance (O\&M) costs of the hatchery operations. Therefore, this project will pay an equitable proportion of the hatcheries O\&M costs, based on the project's share of the total production. Since new production is expected to total 23,331 pounds, and since the total production at $\mathrm{RBH} / \mathrm{Pelton}$ Ladder has recently averaged 84,000 pounds at a cost of $\$ 259,000$, the project will pay 21.7 percent of the annual O\&M costs. This cost, which is estimated to be $\$ 62,200$ for the first brood, would cover the costs of rearing, tagging and marking the smolts.

BPA will pay transport costs associated with trucking 15,554 pounds of smolts to targeted outplant sites annually.

PGE has suggested that project biological personnel may be able to share office space with on-site biologists hired by the utility. If this accommodation can be arranged, the project can save substantial office funds.

\section{Capital Costs}

Capital construction costs are difficult to estimate precisely without the benefit of detailed engineering studies. Preliminary estimates indicate, however, that all necessary capital improvements can be accomplished for less than $\$ 100,000$. Even if unforeseen contingencies should result in the doubling of this capital outlay to $\$ 200,000$, the capital construction costs of the project would be only $\$ 8.57$ per smolt-pound capacity.

Capital costs at RBH that would be assessed as part of this project include:

- Installation of additional facilities for chilling water in the incubation system at RBH.

- Additional trays for the existing RBH Heath incubators.

- Minor modifications to the RBH brood pond to facilitate ponding changes needed to start extra fish. 
Capital costs that would be associated with the Pelton Ladder modifications include:

- Construction of a headbox to divert rearing water, including appropriate flow-control structures.

- Adequate drum screens to prevent fish movement between rearing cells.

- Diversion piping from the headbox to the lower section of rearing cells, including insulating earth cover if deemed necessary as protection against freezing.

- Provision of diversion piping from the upper rearing section to Pelton Reregulating Reservoir.

- Improvement of access roadways to the new rearing section, where required.

- Gripstrut walkways and appropriate handrails at critical locations to facilitate safety during feeding and sampling activities.

- Installation of appropriate water-level alarms in the rearing cells of Pelton Ladder.

- Provision of a temporary fish-retention area to facilitate loading and transport of smolts for outplanting.

\section{Personal Services}

Personal services costs associated with ODFW employees include a biologist who will be stationed at RBH. This person's duties will include overseeing all monitoring and evaluation operations at the hatchery and ladder; assisting with hatchery production of test and control fish; monitoring of growth-control activities and fish-health procedures; coordinating management and structure processes; compiling and analyzing collected data; and providing written and oral progress reports. This biologist will work closely with hatchery management staff to assist in developing effective fish sampling and collection procedures, and ponding plans. They will also help coordinate fish-identification (tagging and marking) operations.

The project biologist will receive the following annual support:

- Seasonally-hired biological aide to assist with critical periods of field work (two person months)

- Secretarial (approximately two weeks per year)

- Supervisory biologist for facilitating policy oversight (approximately two weeks per year)

The CTWS will also provide the services of a biologist for two months per year. This individual will provide co-management coordination to the study and supervision of the seasonal employees conducting the field-sampling operations (i.e., monitoring of fisheries at Sherars Falls, investigation of development of lower-river fisheries, and documentation of hatchery-fish incursion into natural spawning areas). This CTWS biologist will also have responsibilities for coordination of management and structure processes with CTWS, and will be the primary liaison between the project and the WSNFH operations. Additional responsibilities will include assistance with project data compilation and analyses, and reporting requirements. This person will be assisted seasonally by six person-months of technician time to conduct field sampling, one 
half month per year of secretarial support, and about two weeks per year of supervising biologist time for policy oversight.

Personal services budget estimates for conducting the monitoring and evaluations studies for FY 1990 and 1991 appear in Tables 7 and 8, respectively.

\section{Estimated Study Budget}

Table 9 displays the estimated budget for all phases of the study from FY 1990 to 1999. Although the budget includes a rough estimate of capital construction costs, these costs must be subjected to additional engineering analysis. All long-term budget projections include an annual inflation factor of 5 percent, although actual increases will likely vary. 
Table 7. Estimated FY 1991 (July 1,1991 - April 30.1992) budget Pelton Lake monitoring and evaluation program.

OREGON DEPARTMENT OF FISH AND WILDLIFE

Personal Services

Position
Project Leader (Bio 2)
EBA-1
PEM-D
Clerical Specialist

\section{Supplies and Services}

Vehicle, mileage, travel Off ice, utilities, office supplies Communications and printing Field supplies

Indirect Costs (21.6\% of P.S. and S \& S)

Caoital Outlay

Engineering design, and construct facility modifications
Subtotal S \$ S

\begin{tabular}{crrrr} 
Months & Rate & Amount & Total \\
\cline { 3 - 4 } 0 & & & & \\
0 & $\$ 2,547$ & $\$$ & 0 & \\
0 & 1,296 & & 0 & \\
0 & 3,370 & & 0 & \\
O.P.E. (40\%) & 1,581 & & 0 & \\
Subtotal P.S. & & & 0 & \\
& & $\$$ & 0 & $\$ 0$
\end{tabular}
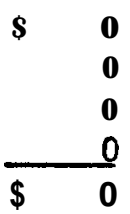

S 0

$\$ 0$

$\$ 0$

EST $\$ 100,000$

\section{CONFEDERATED TRIBES OF WARM SPRINGS}

\section{Personal Services}

Positions
Biologist
F.W. Supervisor
F.W. Technician
Secretary

Services and Supplies

Vehicle, mileage, travel

Office, utilities, office-supplies

Communications and printing

Field suppiies

indirect costs $(51.5 \%$ of P.S. and S \& S)

Capital Outlay

None proposed
Subtotal S \& S

\begin{tabular}{|c|c|c|c|c|}
\hline Months & Rate & \multicolumn{2}{|c|}{ Amount } & Total \\
\hline 0 & $\$ 2,154$ & $\$$ & 0 & \\
\hline 0 & 3,024 & & 0 & \\
\hline 0 & 1. 300 & & 0 & \\
\hline 0 & 1,325 & & 0 & \\
\hline \multicolumn{2}{|c|}{ O.P.E. ( $30 \%)$} & & 0 & \\
\hline \multicolumn{2}{|c|}{ Subtotal P.S. } & $\$$ & 0 & $\$ 0$ \\
\hline
\end{tabular}

$\$ 0$

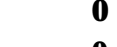

$\$ 0$

$\$ 0$

\$ $\mathbf{0}$

$\$ 0$ 
Table 8. Estimated FY 1992 (May 1, 1992 to April 30, 1993) budget Pelton Ladder monitoring and evaluation program.

\section{OREGON DEPARTMENT OF FISH AND WILDLIFE}

\section{Personal Services}

Position
Project Leader (Bio 2)
EBA-1
PEM-O
Clerical Specialist

Suoolies and Services

Vehicle, mileage, travel Office, utilities, office supplies

Communications and printing Field supplies

Indirect Costs (21.6\% of P.S. and S \& S)

Subtotal S \& S

$\begin{array}{crrr}\text { Months } & \text { Rate } & \text { Amount } \\ & & \\ 12.0 & \$ 2,674 & \$ 32,092 \\ 2.0 & 1,362 & 2,742 \\ 0.5 & 3,539 & 1,769 \\ 1.0 & 1,660 & 1,660 \\ \text { O.P.E. (40\%) } & & 15,298 \\ \text { Subtotal P.S. } & & \$ 53,543\end{array}$

$\$ 53,543$

\begin{tabular}{lrr} 
& $\$ 4,000$ & \\
7,000 & \\
3,000 & \\
1.000 & \\
\hline Subtotal S \& S & $\$ 15,000$ & $\$ 15.000$ \\
& $\$ 14,805$ & $\$ 14,805$
\end{tabular}

Capital Outlay

Office equipment

Microcomputer and software

Total ODFW Budget

$\$ 83,348$

CONFEDERATED TRIBES OF WARM SPRINGS

Personal Services

Position
Biologist
F.W. Supervisor
F.W. Technician
Secretary

Services and Suoolies

Vehicle, mileage, travel

Office, utilities, office supplies

Communications and printing

Field supplies

Indirect costs (50.5\% of P.S. and S \& S)

Caoital Outlay

$\begin{array}{crrr}\text { Months } & \text { Rate } & \text { Amount } \\ & & \\ 2.0 & \$ 2,262 & \$ 4,524 \\ 0.5 & 3,175 & 1,588 \\ 6.0 & 1,365 & 8,190 \\ 0.5 & 1.391 & 696 \\ \text { O.P.E. (30\%) } & & 4.499 \\ \text { Subtotal P.S. } & & \$ 19,497\end{array}$

Total

$\$ 19,497$ 
Table 9. Estimated tolal budget Pelton Ladder study and fish production, 1991- 2000

\begin{tabular}{lcccrrr} 
& & & \multicolumn{2}{r}{ M \& E Budget } & Capital \\
FY & & Months & 'ODFW & CTWS & Construction \\
1991 & $10 / 01 / 91-04 / 30 / 92$ & 7 & 0 & 0 & 20,000 (engineer) \\
1992 & $05 / 01 / 92-04 / 30 / 93$ & 12 & 89,148 & 37,870 & 80,000 (construction) \\
1993 & $05 / 01 / 93-04 / 30 / 94$ & 12 & 87,515 & 39,764 & \\
1994 & $05 / 01 / 94-04 / 30 / 95$ & 12 & 91,891 & 41,752 & \\
1995 & $05 / 01 / 95 \cdot 04 / 30 / 96$ & 12 & 96,485 & 43,839 & \\
1996 & $05 / 01 / 96 \cdot 04 / 30 / 97$ & 12 & 101,310 & 46,031 & \\
1997 & $05 / 01 / 97 \cdot 04 / 30 / 98$ & 12 & 106,376 & 48,333 & \\
1998 & $05 / 01 / 98 \cdot 04 / 30 / 99$ & 12 & 111,694 & 50,749 & \\
1999 & $05 / 01 / 99-04 / 30 / 00$ & 12 & 68,413 & 31,084 &
\end{tabular}

\begin{tabular}{rr}
$\begin{array}{c}\text { Fish } \\
\text { Rearing/ } \\
\text { Marking }\end{array}$ & $\begin{array}{l}\text { Round } \\
\text { Total }\end{array}$ \\
0 & 20,000 \\
\hline 62,200 & 270,000 \\
\hline 65,310 & 193,000 \\
\hline 68,576 & 202,000 \\
\hline 72,004 & 212,330 \\
\hline $75,604 @$ & 223,000 \\
\hline $79,384 @$ & 234,000 \\
\hline $83,353 @$ & 246,000 \\
\hline $87,521 @$ & 187,000
\end{tabular}

@Assumes production and tagging of smolts will continue after study broods are released. 


\section{SUMMARY}

\section{Project Benefits}

Rearing additional fish in Pelton Ladder provides fishery managers with a low-cost alternative to making major financial investments in new formal hatchery facilities. Adult chinook returning from this rearing program will help bolster the dwindling runs of "upriver" spring chinook, thus assisting the Council's goal for increased production of this species. The Deschutes River Subbasin Plan envisions need for additional return of hatchery-produced spring chinook in order to meet goals for increased harvest opportunity.

Spring chinook released from Pelton Ladder will contribute little to offshore fisheries, as we can account for only about 1 percent of the RBH contribution in offshore fisheries. Based on past performance, we expect 6 percent of the adults produced will be caught in sport, commercial, and tribal subsistence fisheries in the Columbia River. Most benefits of the extra adults produced will be realized in the Deschutes River in the form of increased sport and tribal harvests and increased returns to RBH. Adults collected at Pelton Ladder above production needs will be provided to the CTWS.

Return of more adults to the Deschutes River will continue the trend of increased abundance of spring chinook noted since 1985. Rearing of fish in the ladder under the proposed program will provide ODFW and CTWS co-management opportunity, and the associated monitoring and evaluation studies will refine ODFW's ability to effectively manage the RBWPelton Ladder rearing program and will provide inferences about the ability to further employ the fish-rearing potential of unused sections of the fish ladder.

We envision outplanting the majority of smolts produced in the new ladder section. Because of unique survival and adult-production attributes, low cost and excellent quality, chinook smolts produced in Pelton Ladder represent an unparalleled opportunity to restore or improve runs of spring chinook to other Columbia River tributaries that may be designated as appropriate donor streams. Under recent decisions made by ODFWs Pathology section, smolts reared in Pelton Ladder can be transported to other Columbia River tributaries as supplementation needs dictate, with the stipulation that these smolts pass an extensive pathology examination prior to transport. The Council's Northeast Oregon Fish Project has identified the need for good quality smolts to reinstate runs of spring chinook in Hood River, and ODFW's Fish Division has approved the concept of releasing Deschutes River stock spring chinook into the Hood River system.

ODFW and CTWS have continuing interest in increasing the runs of naturally produced spring chinook in the Deschutes River Subbasin, and the White River Project is identified as the most practical and potentially effective measure for achieving this goal. If related problems are eventually solved and passage for anadromous fish is provided at White River Falls, spring chinook smolts outplanted from Pelton Ladder will be among the first choices as vehicles for efforts to initiate self-sustaining runs of salmon in this previously inaccessible area of the Deschutes River Subbasin. 


\section{Project Impacts}

Even with the considerable precautions we have taken to design project operations to minimize effects on naturally produced fish in the Deschutes subbasin, a minor level of increases in releases of hatchery-produced fish will occur. This introduces a degree of uncertainty about interactions between naturally-produced and hatchery fish.

We have intentionally limited the number of ladder-reared spring chinook smolts to be released in the vicinity of the entrance to Pelton Ladder, and we prescribe that additional smolts produced will be transported to the Hood River Subbasin for release.

We intend to monitor the catches of adult wild and hatchery chinook in the Deschutes River fisheries over the term of the study to determine if total catch of spring chinook increases, as desired, or if the increased total catch includes an undesirably-high level of naturally produced fish. In addition, we will make carcass surveys of the spawning areas to determine if hatcheryproduced salmon begin to encroach into these critical areas of natural production. We intend to maintain the program of isolating wild from hatchery,spring chinook in the lower Deschutes River, as is currently practiced.

Results of these field studies, conducted concurrently with return of adult spring chinook from the Pelton Ladder project, will detect whether the project is providing undesired effects that could compromise our ability to effectively maintain separate management of hatchery and natural stocks in the river. If this happens, we have the obligation to change the production program, the release strategy employed, or the harvest management.

We have prescribed facility changes that should minimize effects upon the currently effective hatchery program at $\mathrm{RBH}$ and in Pelton Ladder, but some uncertainty remains. We propose to employ hatchery-effectiveness studies designed to detect how the new rearing program affects survival rates from released smolt to returning adult, thus permitting us the opportunity to correct observed deficiencies, if needed.

\section{Harvest}

Based upon long-term average survival rates observed for spring chinook reared in Pelton Ladder, we expect that the expanded production potential of the ladder will yield adult spring chinook that will return to the Deschutes River at rates of 1.6 percent of the smolts released.

Current harvest rates of these fish in the Deschutes River average about 30 percent of the available adults.

We have no comparable data upon which to estimate survival rates of smolts from Pelton Ladder which would be outplanted to alternate areas for release. We have hypothesized that ladder-reared smolts benefit from not having been handled during release; they are currently allowed to emigrate without handling from the ladder when barriers in the ladder are removed in April. We suspect fish pumped out of the ladder and transported by truck to other areas will experience handling stress which may result in some degree of reduced survival. Harvest of the survivors thus outplanted will depend on the harvest management protocol being implemented in the recipient subbasin. However, if Deschutes River stocks are reared for outplanting, we expect the primary harvest location to occur in the stream where the smolts are released. 


\section{Monitoring and Evaluation}

The monitoring and evaluation plan developed for this program is designed to assess whether program goals are being met. Program goals include evaluation of the effects of ladder modification on the ability of the ladder to produce effective spring chinook smolts, and this analysis provides the inference that if the existing expansion is successful, we may be able to make further use of the potential of the ladder to rear fish. In addition, the program goals include the need to identify hatchery practices at the RBH/Pelton Ladder complex that not only promote survival rates from released smolt to returning adult, but also protect naturally-rearing fish in the Deschutes subbasin.

Specific hatchery-effectiveness experiments within the monitoring and evaluation program include controlled tests with tagged smolts to assess effects of smolt size on survival rate, survival effects of time of transfer of rearing juveniles from $\mathrm{RBH}$ to Pelton Ladder, and continued comparison of the relative survival rates observed between RBH-produced and Pelton Ladderproduced smolts. Field studies are designed to document possible genetic impacts: harvest of adults produced, potential changes in hatchery/natural composition of the catch, and potential changes in rate of straying of hatchery-generated adults into natural production areas. Although we reserve the option to attempt to evaluate changes to populations of trout and other resident fishes in the subbasin as the result of increased hatchery production, we prefer to prudently limit the volume of smolts released. We believe the poor statistical sensitivity involved with fish sampling in a large river like the Deschutes makes valid comparisons of pre-project and post-project populations difficult. 


\section{REFERENCES}

Busack, C. 1990. Yakima/Klickitat production project, genetic risk assessment. Unpublished report. Washington Department of Fisheries. Olympia, Washington.

Columbia Basin Fish and Wildlife Authority. 1990. Integrated System Plan for salmon and steelhead production in the Columbia River Basin. Public review draft. Northwest Power Planning Council. Portland, Oregon.

Cramer, S.P. 1991. Genetic risk assessment of the Hood River component, Northeast Oregon Salmon and Steelhead Facilities. Progress Report to the Nez Perce Tribal Executive Committee and Nez Perce Fisheries Resource Management. S.P. Cramer and Associates, Fisheries Consultants. Corvallis, Oregon.

Hood River Production Master Plan. 1991. Draft master plan prepared for the Northwest Power Planning Council by the Confederated Tribes of the Warm Springs Indian Reservation and Oregon Department of Fish and Wildlife. Warm Springs and Portland, Oregon.

Kapuscinski, A.R. 1991. Genetic analysis of policies and guidelines for salmon and steelhead hatchery production in the Columbia River basin. Executive summary prepared for the NPPC. University of Minnesota, St. Paul, Minnesota.

King, S. and D. McIsaac, eds. 1989. Status report, Columbia River fish runs and fisheries, 19601988. Oregon Department of Fish and Wildlife and Washington Dept. Fisheries, Joint report, Portland, Oregon.

Lindsay, R.B and B. C. Jonasson. 1989. An evaluation of spring chinook salmon rearing program at Round Butte Hatchery. Oregon Department of Fish and Wildlife, Fish Research Project F-88-R, Interim Report, Portland, Oregon.

Lindsay, R.B., B.C. Jonasson, R.K. Schroeder, and B.C. Cates. 1989. Spring chinook salmon in the Deschutes River, Oregon. Oregon Department of Fish and Wildlife, Information Report, Portland.

NEOH Project (Northeast Oregon Hatchery Project). 1991. Hood River Master Plan. Draft monitoring and evaluation plan produced for NPPC's Monitoring and Evaluation Group review. Confederated Tribes of Warm Springs, Warm Springs, Oregon.

Northwest Power Planning Council. 1987. Columbia River Basin Fish and Wildlife Program. Portland, Oregon.

Oregon Department of Fish and Wildlife. 1987. United States vs. Oregon subbasin production reports. Oregon Department of Fish and Wildlife, Portland.

Oregon Department of Fish and Wildlife. 1989. Deschutes River Subbasin Plan, Draft report presented to the Northwest Power Planning Council, Portland.

Oregon Department of Fish and Wildlife, U.S. Forest Service, Ott Water Engineers, and Bull \& Associates, Inc. 1985. White River Falls Passage Project, Tygh Valley, Oregon. Fish Research Project DE-A179-84BP12910, Final technical report, Volume 1. Portland, Oregon. 
OSGC (Oregon State Game Commission). 1949. A protest on granting a preliminary permit for hydroelectric project number 170. Document to the Federal Power Commission (now Federal Energy Commission) from the Oregon State Game Commission dated April 1949, Portland.

Ratliff, D.E. 1981. Cerutomyxa shasta Epizootiology in chinook salmon of central Oregon. Transactions of the American Fisheries Society 110:507-513.

Ratliff, D.E. 1983. Cerutomyxu shasta: Longevity, distribution, timing and abundance of the infective stage in central Oregon. Canadian Journal of Fisheries and Aquatic Sciences 40:1622-1632.

Riggs, L. 1990. Principles for Genetic Conservation and Production Quality. Northwest Power Planning Council, Contract C90-005. Portland, Oregon.

State of Oregon. Oregon Administrative Rules, Chapter 635, Division 7 - Department of Fish and Wildlife, revised 1990, Portland.

U.S. Bureau of Land Management. 1985. Two Rivers Management Plan. Draft Environmental Impact Statement. Appendix P., Wildlife Habitat Interrelationships. Prineville, Oregon.

Wade, M.G., D.V. Buchanan and S.P. Trask. Restoration of the native winter steelhead run on the South Santiam River above Foster Dam. Oregon Department of Fish and Wildlife annual progress report, Contract DACW57-85-C0068. Portland, Oregon.

Walters, T.R. 1989. Use of production potential at twenty-five fish propagation facilities operated by the Oregon Department of Fish and Wildlife. Oregon Department of Fish and Wildlife, Technical Services. Corvallis, Oregon. 